medRxiv preprint doi: https://doi.org/10.1101/2021.05.03.21256468; this version posted May 5, 2021. The copyright holder for this preprint (which was not certified by peer review) is the author/funder, who has granted medRxiv a license to display the preprint in perpetuity.

\title{
Lipid-Modulating Agents for Prevention or Treatment of COVID-19 in Randomized Trials
}

Azita H. Talasaz, PharmD, 1,2,3 Parham Sadeghipour, MD, ${ }^{4}$ Maryam Aghakouchakzadeh, PharmD, ${ }^{1}$ Isaac Dreyfus, MD, ${ }^{5}$ Hessam Kakavand, PharmD, ${ }^{1}$ Hamid Ariannejad, MD, ${ }^{2}$ Aakriti Gupta, MD, MS, 5,6,7 Mahesh V. Madhavan, MD, MS, 5,6 Benjamin W. Van Tassell, PharmD, ${ }^{3,8}$ David Jimenez, MD, PhD, ${ }^{9}$ Manuel Monreal, MD, PhD, ${ }^{10}$ Muthiah Vaduganathan, MD, MPH, 11 John Fanikos, R.Ph, MBA, ${ }^{12}$ Dave L Dixon, PharmD, ${ }^{3,8}$ Gregory Piazza, MD, MS, ${ }^{11}$ Sahil A. Parikh, MD, 5,6 Deepak L. Bhatt, MD, MPH, ${ }^{11}$ Gregory YH Lip, MD, ${ }^{13,14}$ Gregg W. Stone, MD, ${ }^{6,15}$ Harlan M. Krumholz, MD, SM, ${ }^{7,16,17}$ Peter Libby, MD, ${ }^{11}$ Samuel Z. Goldhaber, MD, ${ }^{11}$ and Behnood Bikdeli, MD, MS 7,8,11,*

Total Words Count: 7,771 (including text, tables, Figure legends, but not online supplement) Affiliations

1. Department of Clinical Pharmacy, Faculty of Pharmacy, Tehran University of Medical Sciences, Tehran, Iran.

2. Tehran Heart Center, Tehran University of Medical Sciences, Tehran, Iran.

3. Department of Pharmacotherapy and Outcome Science, School of Pharmacy, Virginia Commonwealth University, Richmond, Virginia, USA.

4. Cardiovascular Intervention Research Center, Rajaie Cardiovascular Medical and Research Center, Iran University of Medical Sciences, Tehran, Iran.

5. NewYork-Presbyterian Hospital/Columbia University Irving Medical Center, New York, New York

6. Clinical Trials Center, Cardiovascular Research Foundation, New York, NY, USA.

7. Center for Outcomes Research and Evaluation (CORE), Yale School of Medicine, New Haven, CT, USA.

8. Pauley Heart Center, Division of Cardiology, Department of Internal Medicine, School of Pharmacy, Virginia Commonwealth University, Richmond, Virginia, USA. 
medRxiv preprint doi: https://doi.org/10.1101/2021.05.03.21256468; this version posted May 5, 2021. The copyright holder for this preprint (which was not certified by peer review) is the author/funder, who has granted medRxiv a license to display the preprint in perpetuity.

All rights reserved. No reuse allowed without permission.

9. Respiratory Department, Hospital Ramón y Cajal and Medicine Department, Universidad de Alcalá (Instituto de Ramón y Cajal de Investigación Sanitaria), Centro de Investigación Biomédica en Red de Enfermedades Respiratorias, Madrid, Spain.

10. Department of Internal Medicine, Hospital Universitari Germans Trials i Pujol, Universidad Católica San Antonio de Murcia, Barcelona, Spain.

11. Division of cardiovascular Medicine Division, Brigham and Women's Hospital, Harvard Medical School, Boston, MA, USA.

12. Department of Pharmacy, Brigham and Women's Hospital, Harvard Medical School, Boston, MA, USA.

13. Liverpool Centre for Cardiovascular Science, Liverpool Heart and Chest Hospital, University of Liverpool, Liverpool, United Kingdom.

14. Department of Clinical Medicine, Aalborg University, Aalborg, Denmark.

15. Zena and Michael A. Wiener Cardiovascular Institute, Icahn School of Medicine at Mount Sinai, New York, NY, USA.

16. Department of Health Policy and Administration, Yale School of Public Health, New Haven, CT, USA.

17. Section of Cardiovascular Medicine, Department of Internal Medicine, Yale School of Medicine, New Haven, CT, USA.

FUNDING: None

ADDRESS FOR CORRESPONDENCE: Dr. Bikdeli, Cardiovascular Medicine Division, Brigham and Women's Hospital, 75Francis Street, Shapiro 5, Suite 5156. Boston, MA 02115; Phone: (617) 732-6984, Fax: (617) 738-7652, Email: bbikdeli@bwh.harvard.edu, Behnood.bikdeli@yale.edu

\section{ABSTRACT}


medRxiv preprint doi: https://doi.org/10.1101/2021.05.03.21256468; this version posted May 5, 2021. The copyright holder for this preprint (which was not certified by peer review) is the author/funder, who has granted medRxiv a license to display the preprint in perpetuity.

All rights reserved. No reuse allowed without permission.

Coronavirus disease 2019 (COVID-19) is associated with systemic inflammation, endothelial activation, and multi-organ manifestations. Lipid modulating agents may be useful in treating patients with COVID-19. They may inhibit viral entry by lipid raft disruption or ameliorate the inflammatory response and endothelial activation. In addition, dyslipidemia with lower highdensity lipoprotein cholesterol and higher triglycerides portends worse outcome in patients with COVID-19. Upon a systematic search, 40 RCTs with lipid modulating agents were identified, including 17 statin trials, 14 omega-3 fatty acids RCTs, 3 fibrates RCTs, 5 niacin RCTs, and 1 dalcetrapib RCT for management or prevention of COVID-19. This manuscript summarizes the ongoing or completed randomized controlled trials (RCTs) of lipid modulating agents in COVID19 and the implications of these trials for patient management.

KEY WORDS COVID-19, lipid modulating agent, statin, fibrate, omega3, niacin

\author{
ABBREVIATIONS AND ACRONYMS \\ ACE2 = angiotensin converting enzyme 2 \\ ARDS $=$ acute respiratory distress syndrome \\ CETP $=$ cholesterol ester transfer protein \\ COVID-19 = coronavirus disease 2019 \\ $\mathrm{HDL}=$ high-density lipoprotein \\ HMG-CoA = 3-hydroxy-3-methyl-glutaryl-coenzyme A \\ ICU $=$ intensive care unit \\ $\mathrm{NAD}=$ nicotinamide adenine dinucleotide \\ $\mathrm{RCT}=$ randomized controlled trial
}

SARS-CoV-2 = severe acute respiratory syndrome coronavirus 2 
medRxiv preprint doi: https://doi.org/10.1101/2021.05.03.21256468; this version posted May 5, 2021. The copyright holder for this preprint (which was not certified by peer review) is the author/funder, who has granted medRxiv a license to display the preprint in perpetuity.

All rights reserved. No reuse allowed without permission.

\section{INTRODUCTION}

Severe acute respiratory syndrome coronavirus 2 (SARS-CoV-2) cellular entry is mediated by attachment to angiotensin converting enzyme 2 (ACE2). Lipid rafts - plasma membrane microdomains mainly composed of cholesterol, glycosphingolipids, and phospholipids, capable of changing their composition in response to stimuli - may play a critical role in this process (1). SARS-CoV-2 can trigger an uncontrolled innate inflammatory response (cytokine storm) leading to local and systemic tissue damage commonly seen in advanced coronavirus disease 2019 (COVID-19) (2). Inflammation and resultant endothelial injury may lead to a hypercoagulable state and predispose patients to micro and macrothrombosis $(3,4)$.

Lipid modulating agents may limit inflammation and thromboinflammation in COVID-19 by exerting anti-viral, anti-inflammatory, immunomodulatory, and antithrombotic effects (5). Moreover, lower high-density lipoprotein (HDL) cholesterol and higher triglycerides are associated with worse outcomes in patients with COVID-19 (6). Through lipid raft disruption (7), lipid profile improvement, and other effects, lipid modulating agents may impact the outcomes of patients with COVID-19. Moreover, as previously seen in other SARS infections, SARS-CoV-2 infection may lead to the MYD88 gene being highly induced with resultant activation of the nuclear factor kappa-light-chain-enhancer of activated B cells (NF-kB) pathway $(8,9)$. Statins had inhibitory effects on this pathway, (and a reduction in type 1 interferon) and hyperinflammation $(10,11)$.

This manuscript summarizes systematically the randomized controlled trials (RCTs) evaluating lipid modulating therapies for the prevention or treatment of COVID-19. The presumed mechanisms of action, existing knowledge of RCTs, as well as knowledge gaps that may influence the design of future trials will be highlighted. 
medRxiv preprint doi: https://doi.org/10.1101/2021.05.03.21256468; this version posted May 5, 2021. The copyright holder for this preprint (which was not certified by peer review) is the author/funder, who has granted medRxiv a license to display the preprint in perpetuity.

\section{METHODS}

\section{Data Source and Search Strategy}

We searched ClinicalTrials.gov and the World Health Organization International Clinical Trials Registry Platform (WHO-ICTRP) for the identification of RCTs investigating lipid modulating agent trials in COVID-19 (date of last search: March 31, 2021). We used key words for COVID19 or SARS-CoV-2 or coronavirus disease 2019 and statins (including atorvastatin, rosuvastatin, simvastatin, fluvastatin, lovastatin, pitavastatin, and pravastatin), fibrates (including fenofibrate, clofibrate, bezafibrate, gemfibrozil, and pemafibrate), ezetimibe, bile acid sequestrants (colesevelam, cholestyramine, colestipol), proprotein convertase subtilisin/kexin type 9 (PCSK9) inhibitors (including, alirocumab, evolocumab, and inclisiran), omega-3 fatty acids (including icosapent ethyl, eicosapentaenoic acid [EPA], and docosahexaenoic acid [DHA]), niacin, nicotinic acid, nicotinamide, vitamin B3, evinacumab, mipomersen, lomitapide, bempedoic acid, and cholesteryl ester transfer protein (CETP) inhibitors (anacetrapib, dalcetrapib, evacetrapib, torcetrapib, and TA-8995).

We separated the RCTs in which these agents were used for treatment of patients with COVID-19 versus those used for prevention of the development (or severity) of COVID-19. Study eligibility criteria for inclusion in this review were RCT design with a lipid modifying agent and description of inclusion and exclusion criteria and the primary outcome at clinicaltrials.gov or WHO-ICTRP. Figure 1 describes the search strategy and screening of the studies. For RCTs that met the above eligibility criteria, we searched MEDLINE with PubMed Interface, Google scholar, and pre-print servers including medrxiv.org and biorxiv.org for published design papers or final result manuscripts. 
medRxiv preprint doi: https://doi.org/10.1101/2021.05.03.21256468; this version posted May 5, 2021. The copyright holder for this preprint (which was not certified by peer review) is the author/funder, who has granted medRxiv a license to display the preprint in perpetuity.

\section{Summary of the Search Results}

We screened 255 records, of which 97 required further manual review. Ultimately, 40 RCTs met the eligibility criteria, of which 36 were related to the management of COVID-19: 17 for statins, 10 for omega-3 fatty acids, 3 for fibrates, 5 for niacin, and 1 for dalcetrapib. In addition, 4 RCTs of omega-3 fatty acids were identified for the prevention of COVID-19. We did not identify RCTs for ezetimibe, bile acid sequestrants, PCSK9 inhibitors, evinacumab, mipomersen, lomitapide, bempedoic acid, or CETP inhibitors other than dalcetrapib for the management or the prevention of COVID-19. A summary of methodological features of the ongoing RCTs categorized by drug class is provided in Table 1. In this table, we describe factors such as number of enrollees, comparator types, blinding, type of primary outcomes (clinical or surrogate outcomes), blinded outcome adjudication, and the existence of published design paper are included. For 7 studies, a design paper or study protocol was available (12-18). Of all RCTs, only 1 has reported the results (at the National Lipid Association Virtual Scientific Sessions) (19).

\section{Potential mechanisms of action lipid modulating agents in patients with COVID-19}

Figure 2 illustrates the potential pathways through which lipid modulating drugs that have ongoing RCTs may impact the outcomes in COVID-19. These agents include statins, omega-3 fatty acids, fibrates, niacin, and dalcetrapib.

Statins inhibit 3-hydroxy-3-methyl-glutaryl-coenzyme A (HMG-CoA) reductase (20) and the production of isoprenoid intermediates that are critical for viral entry, immune signaling, and the inflammatory cascade (21). These agents also induce transcription factors such as Krüppel-like factor-2, limiting inflammation and prothrombotic functions of activated endothelial cells (22). Statins exert antioxidant and anti-apoptotic effects, potentiate the production of nitric oxide (3, 
medRxiv preprint doi: https://doi.org/10.1101/2021.05.03.21256468; this version posted May 5, 2021. The copyright holder for this preprint (which was not certified by peer review) is the author/funder, who has granted medRxiv a license to display the preprint in perpetuity.

All rights reserved. No reuse allowed without permission.

23), and upregulate transforming growth factor beta receptor III, thereby reducing collagen deposition and pulmonary fibrosis (24). Data in observational studies, RCTs, and meta-analyses in patients with sepsis are controversial. Two recent RCTs showed no improvement in acute respiratory distress syndrome (ARDS) versus placebo $(25,26)$. However, some studies suggest a benefit associated with statin use. (27) Secondary analysis of the HARP-2 trial, suggested potential improved survival in patients with a high inflammatory status (28). In a meta-analysis of cohort studies and RCTs of patients with ARDS, statin use was not associated with reduced mortality in patients with acute lung injury, but correlated with increased ventilator-free days and reduced sequential organ failure assessment scores (29). In COVID-19, a recent single center retrospective study suggested lower adjusted mortality rates in patients with antecedent statin use compared with non-users (30).

Omega-3 polyunsaturated fatty acids act as a precursor to lipid mediators that reduce inflammation and may prove beneficial in the COVID-19 inflammatory response (14). Icosapent ethyl, an ethyl ester of EPA, has demonstrated anti-inflammatory properties (15). Multiple RCTs have evaluated omega-3 polyunsaturated fatty acids in ARDS. Although individual trial results have been mixed, a meta-analysis showed favorable outcomes with regard to ventilator-free days, length of stay in the intensive care unit (ICU), organ failure, and mortality in patients receiving a diet enriched with EPA and gamma-linolenic acid $(31,32)$.

In vitro studies suggest that fenofibrate, a fibric acid derivative, destabilizes the receptor binding domain of the SARS-CoV-2 spike protein and inhibits receptor binding domain binding to ACE2. This may reduce viral infectivity by up to $70 \%$ (33).

Niacin (nicotinic acid, nicotinamide) increases HDL cholesterol and may reduce the inflammatory mediators. Niacin may also possess anti-viral activity through increasing 
medRxiv preprint doi: https://doi.org/10.1101/2021.05.03.21256468; this version posted May 5, 2021. The copyright holder for this preprint (which was not certified by peer review) is the author/funder, who has granted medRxiv a license to display the preprint in perpetuity.

All rights reserved. No reuse allowed without permission.

nicotinamide adenine dinucleotide (NAD) - as nicotinamide restores poly-adenosine diphosphate (ADP)-ribose polymerases functions - which inhibit the viral replication and support innate immunity to SARS-CoV-2 (34).

CETP inhibitors (e.g., dalcetrapib) raise HDL cholesterol, which may have antiinflammatory properties and inhibit platelet activation (35). However, off-target effects should be considered. In the ILLUMINATE (Investigation of Lipid Level Management to Understand its Impact in Atherosclerotic Events) trial, torcetrapib - another CETP inhibitor -had favorable effects on lipids but showed an increase in death due to sepsis, and increased the systolic blood pressure (36).

\section{SUMMARY OF THE ONGOING RCTS}

A graphical summary of design features of all RCTs for statins, omega-3 fatty acid preparations, fibrates, and niacin for the management of COVID-19 is illustrated in Figures 3, 4, 5, and 6, respectively. In addition, the section on RCTs for the management of patients with diagnosed COVID-19 begins with statin therapy RCTs, followed by RCTs of omega-3 fatty acid preparations, fibrates, niacin, and dalcetrapib. This sequence does not describe treatment preference. Figure 7 illustrates a graphical summary of design features of RCTs for the prevention of COVID-19 (only omega-3 fatty acid had such RCTs). In each section, discussion of these trials is provided according to the clinical setting.

\section{RCTs for Management of Patients with Diagnosed COVID-19}

\section{Ongoing RCTs of statin therapy}


medRxiv preprint doi: https://doi.org/10.1101/2021.05.03.21256468; this version posted May 5, 2021. The copyright holder for this preprint (which was not certified by peer review) is the author/funder, who has granted medRxiv a license to display the preprint in perpetuity.

All rights reserved. No reuse allowed without permission.

Seventeen RCTs of statin therapy have been registered: 16 in the hospitalized setting and 1 in postdischarge setting. These trials assess either moderate-intensity statin therapy (with simvastatin 40 to $80 \mathrm{mg}$ daily or atorvastatin $20 \mathrm{mg}$ daily or rosuvastatin $5 \mathrm{mg}$ daily) or high-intensity statin therapy (with atorvastatin 40 to $80 \mathrm{mg}$ daily or rosuvastatin $40 \mathrm{mg}$ daily) (37).

\section{Ongoing RCTs of statin therapy in hospitalized non-ICU patients}

Statins are being evaluated in 14 RCTs with the number of participants ranging from 40 to 7,100 patients in the non-ICU hospital settings, including 12 for hospitalized non-ICU patients and 2 that enroll both ICU and non-ICU patients (MEDIC-LAUMC [Managing Endothelial Dysfunction in COVID-19: A Randomized Controlled Trial at LAUMC] and Effectiveness and Safety of Medical Treatment for SARS-CoV-2 (COVID-19) in Colombia [NCT04359095]).

Moderate-intensity statin therapy is being tested in 3 of these 14 RCTs for hospitalized non-ICU patients. The primary outcomes include mortality within 90 days in REMAP-CAP (Randomized, Embedded, Multifactorial Adaptive Platform Trial for Community- Acquired Pneumonia) for 7,100 hospitalized non-ICU patients (17), and assessment of COVID-19 severity by WHO scores within 7 days in the Ruxo-Sim-20 trial (Study of Ruxolitinib Plus Simvastatin in the Prevention and Treatment of Respiratory Failure of COVID-19) for 94 participants. The comparators of these trials are no intervention and standard of care (SOC), respectively. The third RCT of moderate-intensity statin therapy, INTENSE-COV, plans to randomize 294 patients to atorvastatin plus lopinavir/ ritonavir (LPV/r) vs. LPV/r for the co-primary outcomes of the proportions of patients with undetectable SARS-CoV-2 polymerase chain reaction (PCR) and Creactive protein $(\mathrm{CRP})<27 \mathrm{mg} / \mathrm{L}$ at day 11 . 
medRxiv preprint doi: https://doi.org/10.1101/2021.05.03.21256468; this version posted May 5, 2021. The copyright holder for this preprint (which was not certified by peer review) is the author/funder, who has granted medRxiv a license to display the preprint in perpetuity.

All rights reserved. No reuse allowed without permission.

High-intensity statin therapy is being assessed in 11 of 14 ongoing RCTs with a total of 8,977 hospitalized non-ICU patients with COVID-19. These 11 RCTs are studying high-intensity statin therapy compared with no treatment ( 2 of 11) or SOC (5 of 11) or placebo (4 of 11). Mortality during hospitalization or within 10 to 30 days is the most common primary outcome in 5 of 11 RCTs with high-intensity statins for hospitalized non-ICU patients $(13,18)$. The HEAL-COVID (HElping Alleviate the Longer-term Consequences of COVID-19) trial plans to enroll 2,631 participants to explore the effect of high-intensity statin therapy on hospital free survival within 12 months from enrollment.

Patients with liver disease are excluded in 2 of 3 RCTs with moderate-intensity and 8 of 11 trials with high-intensity statin. Considerations of drug-drug interactions at the time of enrollment were evaluated in 1 of 3 and 8 of 11 RCTs with moderate- and high-intensity statin RCTs.

\section{Ongoing RCTs of statin therapy in critically ill patients}

Statins are being assessed in 4 RCTs in ICU patients, of which 2 enroll both ICU and non-ICU patients (MEDIC-LAUMC and NCT04359095). Two other RCTs include ICU patients only (INSPIRATION-S [The Intermediate versus Standard-dose Pro-phylactic anticoagulation and Statin In cRitically-ill pATIents with COVID-19: An opeN label randomized controlled trial] with 600 participants (12) and Managing Endothelial Dysfunction in Critically Ill COVID-19 Patients at LAUMCRH [NCT04813471]) with 70 patients with COVID-19.

INSPIRATION-S is the only trial of moderate-intensity statin therapy versus placebo in ICU patients. A composite of all-cause mortality, venous or arterial thrombotic events, and treatment with extracorporeal membrane oxygenation within 30 days is the study primary outcome 
medRxiv preprint doi: https://doi.org/10.1101/2021.05.03.21256468; this version posted May 5, 2021. The copyright holder for this preprint (which was not certified by peer review) is the author/funder, who has granted medRxiv a license to display the preprint in perpetuity.

All rights reserved. No reuse allowed without permission.

(12). INSPIRATION-S recently completed patient enrollment and 30-day results are expected in May 2021.

The remaining RCTs in critically ill patients (3 of 4 trials) are investigating high-intensity statin therapy, of which 2 trials (NCT04813471and NCT04359095) are studying high-intensity statin therapy compared with SOC. The MEDIC-LAUMC is assessing the effects of high-intensity atorvastatin versus placebo among 80 participants. In addition, 2 of 3 trials of high-intensity statin therapy (MEDIC-LAUMC and NCT04813471) consider drug-drug interactions before enrollment, and clinical improvement within 1 month is being assessed as the primary outcome in these two trials. The other trial, NCT04359095, assesses the influence of high-intensity statin therapy on mortality within 28 days as the primary outcome among 1,200 ICU or non-ICU patients. Patients with liver disease are excluded in all of the RCTs with moderate or high-intensity statins for critically ill patients.

\section{Ongoing RCTs of statin therapy in post-discharge patients}

Rosuvastatin (5mg daily) is the only statin-based intervention under investigation in the postdischarge setting. The FJD-COVID-ESTATINAS RCT is evaluating rosuvastatin compared with no treatment in 1,080 patients discharged from hospitalization for COVID19. The primary outcome is a composite of mortality, myocardial infarction, or ischemic stroke within 12 months. Patients with liver disease or concomitant treatment with cyclosporine are excluded. Additional details about ongoing clinical trials of statin therapy are provided in Figure 3.

\section{Ongoing RCTs of omega-3 fatty acid preparations}


medRxiv preprint doi: https://doi.org/10.1101/2021.05.03.21256468; this version posted May 5, 2021. The copyright holder for this preprint (which was not certified by peer review) is the author/funder, who has granted medRxiv a license to display the preprint in perpetuity.

All rights reserved. No reuse allowed without permission.

There are 10 ongoing RCTs evaluating the role of omega-3 fatty acid preparations for the management of COVID-19: 6 RCTs in hospitalized non-ICU patients and 4 ongoing RCTs in the outpatient setting.

\section{Ongoing RCTs of omega-3 fatty acid preparations in hospitalized non-ICU patients}

Omega-3 fatty acids are being evaluated in 6 RCTs with the number of participants ranging from 30 to 284 patients in the non-ICU hospital settings. Most RCTs (5 of 6) assess the oral use of omega-3 fatty acid preparations compared with SOC (3 of 5) or with placebo (1 of 5). The oral use of omega-3 fatty acid preparations plus hydroxychloroquine compared with hydroxychloroquine alone is assessed in the Comparison of the effectiveness of omega-3 and Hydroxychloroquine on Inflammatory factors, liver enzymes, and clinical symptoms in diabetic COVID-19 patients (IRCT20200511047399N1). Only one RCT (NCT04647604 [Resolving Inflammatory Storm in COVID-19 Patients by Omega-3 Polyunsaturated Fatty Acids]) explores intravenous administration of omega-3 fatty acid preparations versus placebo (14). Moreover, 3 of 6 RCTs of hospitalized non-ICU patients have co-primary outcomes including inflammatory markers and lipid levels. Elevated liver enzymes are being evaluated as the safety outcome only in the IRCT20200511047399N1 trial. Patients with liver disease are excluded in 2 of the 6 RCTs of omega-3 fatty acid in hospitalized non-ICU patients.

\section{Ongoing RCTs of omega-3 fatty acid preparations in outpatient setting}

Omega-3 fatty acid preparations are being evaluated in 4 ongoing RCTs for treatment of COVID-

19: KONS-COVID19 (Viruxal Oral and Nasal Spray for Treating the Symptoms of COVID-19), VASCEPA-COVID-19 (An Investigation on the Effects of Icosapent Ethyl (Vascepa ${ }^{\mathrm{TM}}$ ) on 
medRxiv preprint doi: https://doi.org/10.1101/2021.05.03.21256468; this version posted May 5, 2021. The copyright holder for this preprint (which was not certified by peer review) is the author/funder, who has granted medRxiv a license to display the preprint in perpetuity.

All rights reserved. No reuse allowed without permission.

Inflammatory Biomarkers in Individuals With COVID-1), PREPARE-IT 2 (Prevention of COVID19 With EPA in Healthcare Providers at Risk - Intervention Trial 2) and COVID-19 Anosmia Study (NCT04495816) (16).

The KONS-COVID19 trial tests omega-3 inhaled use versus placebo among 128 outpatient participants. The primary outcome is time to clinical improvement within 28 days. The VASCEPA-COVID-19 trial assesses the oral use of icosapent ethyl compared with usual care in a total of 100 outpatient participants. High sensitivity CRP (hsCRP) level is the primary outcome in VASCEPA-COVID-19. Patients with active severe liver disease are excluded in this trial. Initial findings from the VASCEPA-COVID-19 were presented at National Lipid Association Scientific Sessions, and showed that the use of icosapent ethyl for 14 days reduced hs-CRP: 3.2 vs. $1.6 \mathrm{mg} / \mathrm{L}$ $(\mathrm{p}=0.011)$ and led to symptom improvement assessed by InFLUenza Patient-Reported Outcome (FLU-PRO) score in outpatients with COVID-19 after 14 days (19). The PREPARE-IT 2 trial is assessing the effects of icosapent ethyl versus placebo in 2,000 outpatient participants. The impact of oral use of omega-3 fatty acid preparations versus placebo on olfactory performance within 6 weeks among outpatients is under evaluation in the NCT04495816 trial with 126 participants. Additional details about ongoing RCTs of omega-3 fatty acid preparations for treatment of COVID-19 are described in Figure 4.

\section{Ongoing RCTs of fibrates}

There are three RCTs investigating fibrates in patients with COVID-19. These RCTs are testing fenofibrate versus placebo in hospitalized non-ICU patients: FENOC (Fenofibrate for Patients With COVID-19 Requiring Hospitalization), FERMIN (FEnofibRate as a Metabolic INtervention for COVID-19) and Fenofibrate as A Metabolic Intervention for Coronavirus Disease 2019 
medRxiv preprint doi: https://doi.org/10.1101/2021.05.03.21256468; this version posted May 5, 2021. The copyright holder for this preprint (which was not certified by peer review) is the author/funder, who has granted medRxiv a license to display the preprint in perpetuity.

All rights reserved. No reuse allowed without permission.

(COVID-19): A Randomized Controlled Trial (PER-099-20). FERMIN and PER-099-20 also enrolled outpatients. The sample size of these studies ranges from 50 to 700 patients.

The main outcomes in the FENOC include improvement in laboratory markers, the ratio of arterial oxygen partial pressure to fractional inspired oxygen $\left(\mathrm{PaO}_{2} / \mathrm{FiO}_{2}\right)$, and mortality. The composite endpoint as the primary outcome for FERMIN and PER-099-20 trials will be a global rank score that grades patients based on survival, need for respiratory/mechanical support, the fraction of inspired oxygen/ percent oxygen saturation $\left(\mathrm{FiO}_{2} / \mathrm{SpO}_{2}\right)$, the number of days out of the hospital for outpatient participants who are hospitalized after enrollment, and the modified borg dyspnea scale for the outpatient subset not hospitalized. All these trials consider drug-drug interactions prior to the enrollment. Patients with active liver disease are excluded in all 3 of these trials. Additional information about these RCTs is summarized in Figure 5.

\section{Ongoing RCTs of niacin}

Five RCTs of niacin therapy were identified: 2 in hospitalized non-ICU patients, 1 in outpatient setting, and 2 ongoing RCTs in post-acute COVID-19. All of these trials are studying niacin compared with placebo.

\section{Ongoing RCTs of niacin in hospitalized non-ICU patients}

Niacin is being assessed in 2 ongoing RCTs for 100 hospitalized non-ICU patients in each trial: NIRVANA (Nicotinamide Riboside in SARS-CoV-2 (COVID-19) Patients for Renal Protection) and NR-COVID19 (Effects of Nicotinamide Riboside on the Clinical Outcome of Covid-19 in the Elderly) trials. The primary outcomes of these trials are the alteration of blood NAD+ level within 10 days and need for oxygen therapy with a follow-up duration of 90 days, respectively. In 
medRxiv preprint doi: https://doi.org/10.1101/2021.05.03.21256468; this version posted May 5, 2021. The copyright holder for this preprint (which was not certified by peer review) is the author/funder, who has granted medRxiv a license to display the preprint in perpetuity.

All rights reserved. No reuse allowed without permission.

NIRVANA, thrombocytopenia is being evaluated as the safety outcome, and patients with liver disease are being excluded.

\section{Ongoing RCTs of niacin in outpatient setting}

The COVit-2 (Improvement of the Nutritional Status Regarding Nicotinamide (Vitamin B3) and the Disease Course of COVID-19) trial is the only trial of niacin therapy versus placebo in outpatient setting with 840 patients planned to be enrolled. The frequency of complete symptom resolution within 2 weeks is the primary outcome.

\section{Ongoing RCTs of niacin in post-COVID-19 setting}

Niacin is being evaluated in 2 RCTs in the post-COVID-19 setting: Long-COVID (Clinical Trial of Niagen to Examine Recovery in People with Persistent Cognitive and Physical Symptoms After COVID-19 Illness) and Pilot Study Into LDN and NAD+ for Treatment of Patients With PostCOVID-19 Syndrome (NCT04604704) trials. These RCTs assess the oral use of niacin in 100 participants and iontophoresis patches for 60 patients with COVID-19, respectively.

The Long-COVID trial is studying the impact of niacin on the cognitive function of patients with positive PCR at least 2 months prior to enrollment. The primary outcome follow-up duration is 22 weeks. NCT04604704 plans to enroll 60 patients with PCR-confirmed COVID-19 1 to 4 months prior to enrollment. This trial assesses the reduction of fatigue in post-COVID-19 syndrome within 12 weeks as the primary outcome. Patients with liver disease are excluded in the NCT04604704 trial. Additional details about RCTs of niacin are illustrated in Figure 6.

\section{Ongoing RCT of CETP inhibitors}


medRxiv preprint doi: https://doi.org/10.1101/2021.05.03.21256468; this version posted May 5, 2021. The copyright holder for this preprint (which was not certified by peer review) is the author/funder, who has granted medRxiv a license to display the preprint in perpetuity.

All rights reserved. No reuse allowed without permission.

The dal-COVID (Effect of Dalcetrapib in Patients with Confirmed Mild to Moderate COVID-19) trial is the only trial of dalcetrapib $(900 \mathrm{mg}, 1,800 \mathrm{mg}$, and 3,600mg daily) versus placebo in 208 outpatients with mild-to-moderate COVID-19. The primary outcome is time to sustained symptom resolution within 28 days. Patients with liver disease are excluded from NCT04676867 trial. Drugdrug interactions are being considered before enrollment.

\section{RCTs for Prevention of Contracting COVID-19}

Use of omega-3 fatty acid preparations as a preventive measure against COVID-19 is being investigated in 4 RCTs: MITIGATE (A Pragmatic Randomized Trial of Icosapent Ethyl for HighCardiovascular Risk Adults) (15), PREPARE-IT 1 (Prevention of COVID19 With EPA in Healthcare Providers at Risk - Intervention Trial 1), The Effect of Omega-3 on Selected Cytokines Involved in Cytokine Storm (NCT04483271), and The Effect of Omega-3 Supplements on the Serum Levels of ACE/ACE2 Ratio as a Potential Key in Cardiovascular Disease and COVID-19 (NCT04658433).

MITIGATE and PREPARE-IT 1 trials are studying the effects of icosapent ethyl versus placebo. In turn, NCT04483271 and NCT04658433 assess omega-3 fatty acid supplements compared with no treatment for 100 patients in each trial. The number of confirmed viral infections and worst clinical status due to a viral upper respiratory infection are the co-primary outcomes for MITIGATE with 16,500 participants. The number of confirmed viral infections is the primary outcome in PREPARE-IT 1 with 2,000 participants. The primary outcomes for the NCT04483271 and NCT04658433 trials are inflammatory markers such as interleukin-1beta (IL-1 $\beta$ ), IL-6, tumor necrosis factor-alpha, and serum ACE and ACE2. Patients with severe liver disease are excluded only in MITIGATE. Additional details about these RCTs are summarized in Figure 7. 
medRxiv preprint doi: https://doi.org/10.1101/2021.05.03.21256468; this version posted May 5, 2021. The copyright holder for this preprint (which was not certified by peer review) is the author/funder, who has granted medRxiv a license to display the preprint in perpetuity.

All rights reserved. No reuse allowed without permission.

\section{DISCUSSION}

The perspective of the COVID-19 disease state has broadened from pneumonia to a systemic multi-organ disease, with systemic inflammation and thrombosis as key features $(2,38)$. The present review identified 34 RCTs that evaluate the role of lipid modulating agents in the management of acute COVID-19, 2 RCTs in patients with post-acute COVID-19, and 4 RCTs for prevention of contracting (or severity of) COVID-19. Results from these trials may expand the armamentarium for management of COVID-19. The neutral results of recent RCTs of escalateddose anticoagulation in critically-ill patients with COVID-1 $(39,40)$ may indicate the significance of the maladaptive immune response in severe COVID-19 (41). It is in this context that lipid modulating agents with pleotropic effects offer possible therapeutic potential (42). The moderate immunomodulating effect of these agents lessens the chance of excessive immunosuppression and superinfection, commonly seen with other anti-inflammatory agents.

Despite such hope, certain methodological limitations of some of the ongoing RCTs deserve attention. These include small sample size, use of primary surrogate outcomes, and lack of blinded outcome adjudication, which hamper the rigor of the trials. More than one year into the pandemic, 40 RCTs of lipid modifying therapies were identified, with only 21 (with total estimated sample size of 7,675) having double blind design. The results from only one trial have been communicated in preliminary form. In addition, despite the scientific rationale summarized in this manuscript, translation to clinical benefit is not assured. Among the immune-modulating therapies, only steroids have shown consistent efficacy in patients with COVID-19 (43-47). The neutral results with ivermectin (48) and hydroxychloroquine (49), and the mixed results with colchicine 
medRxiv preprint doi: https://doi.org/10.1101/2021.05.03.21256468; this version posted May 5, 2021. The copyright holder for this preprint (which was not certified by peer review) is the author/funder, who has granted medRxiv a license to display the preprint in perpetuity.

All rights reserved. No reuse allowed without permission.

$(50,51)$ and tocilizumab $(52,53)$, remind us that biological plausibility may not translate to meaningful treatment. Hence, the ongoing lipid modulating therapy RCTs are of particular interest.

\section{Statins as Multi-Purpose Drugs?}

Despite initial concern that statins might increase expression of ACE2 and facilitate SARS-CoV2 entry with potential deleterious effects, observational studies suggest an association between antecedent statin use and improved survival. Lee et al. in a population-based propensity matched study of 10,448 patients with COVID-19, showed a significant reduction in hazard of death in statin users compared with non-users (hazard ratio: 0.64 [95\% CI, 0.43-0.95]; P=0.02) (54). Gupta et al. in a retrospective propensity matching analysis of 1,296 patients with COVID-19 reported similar reduction in the odds of death with antecedent statin use (OR: 0.47, 95\% CI 0.36-0.62, p $<0.001$ ) (30). Such non-randomized observational studies are subject to confounding, including confounding by indication, and need confirmation in ongoing RCTs. There are several limitations to the ongoing statin investigations. Several RCTs do not include thrombotic events among their pre-specified outcomes. Quality of life is evaluated in only 3 RCTs. The role of statin therapy in post-discharge setting for patients with COVID-19 is being studied in only 1 RCT with 1080 patients, but not in the outpatient setting.

\section{Omega-3 Polyunsaturated Fatty Acids: Hope or Hype?}

Anti-inflammatory effects (55) and potential impact on ARDS progression (56) make omega-3 fatty acids worthwhile agents for investigation. Functional limitations and quality of life are evaluated exclusively in outpatient trials, while mortality and clinical improvement are evaluated 
medRxiv preprint doi: https://doi.org/10.1101/2021.05.03.21256468; this version posted May 5, 2021. The copyright holder for this preprint (which was not certified by peer review) is the author/funder, who has granted medRxiv a license to display the preprint in perpetuity.

All rights reserved. No reuse allowed without permission.

in hospitalized patients. Two trials with considerable sample size evaluate the role of icosapent ethyl as in prevention of contracting COVID-19.

Several limitations apply to the omega-3 fatty acid RCTs: The total number of patients enrolled in omega-3 fatty acids trials for management of COVID-19 is relatively few (Figure 4). Heterogeneity in use of various formulations (EPA, DHA, or EPA-DHA; ethyl esters vs. free fatty acids)and impurities, and/or oxidative alterations in unregulated supplement preparations makes it more difficult to determine the specific effects of each. Icosapent ethyl will be studied in two large outpatient studies (PREPARE-IT 1 and MITIGATE) trials as a preventive agent, but not in the inpatient setting.

\section{Fibrates: New Spark for a Dying Candle?}

Despite the declining use for cardiovascular risk reduction (57), fibrates may decrease viral entry and SARS-CoV-2 infectivity by increasing sulfatide levels (58) and inhibiting the receptor binding domain to ACE2 (33). Strengths of ongoing fibrate trials include endpoint selection: death, ARDSrelated outcomes, inflammatory markers and invasive mechanical support are the primary outcome under evaluation. Drug interactions were generally considered with fenofibrate initiation. However, fenofibrate is the only fibrate under investigation in RCTs including patients with COVID-19, and its lack of benefit in cardiovascular disease prevention may raise skepticism regarding its utility in COVID-19.

\section{Niacin: Time for a Comeback?}

Anti-inflammatory effects (34) and potential protection against lung injury (59) have made niacin a target for investigation in COVID-19. Niacin is under evaluation in both acute and post-acute 
medRxiv preprint doi: https://doi.org/10.1101/2021.05.03.21256468; this version posted May 5, 2021. The copyright holder for this preprint (which was not certified by peer review) is the author/funder, who has granted medRxiv a license to display the preprint in perpetuity.

All rights reserved. No reuse allowed without permission.

settings. Clinical improvement and symptom resolution are primary outcomes in the majority of RCTs. RCTs in the post-COVID-19 setting will evaluate fatigue and cognitive function for 3 to 6 months.

As with fenofibrate, lack of benefit and presence of adverse effects with nicotinamide seen in prior cardiovascular RCTs $(60,61)$ may dampen excitement for use in COVID-19. Trials in the inpatient and post-acute setting are limited by small sample size and variability in niacin dosing may lead to heterogenous results.

\section{CETP Inhibitors: Room for Potential Benefit?}

Low HDL is associated with increased severity of COVID-19 and correlates with approved biomarkers such as ferritin and D-dimer levels (6). Dalcetrapib will be the first CETP inhibitor to be tested in patients with mild to moderate COVID-19 with time to symptom resolution as the primary outcome. Of note, dalcetrapib did not improve clinical outcomes in those with acute coronary syndromes (62). Among CETP inhibitors, only anacetrapib showed a modest cardiovascular benefit (9\% relative risk reduction) $(63)$, whereas torcetrapib $(64,65)$ led to increase in systolic blood pressure and worse cardiovascular outcomes. Findings from dal-COVID will help clarify whether dalcetrapib merits further testing in COVID-19.

\section{Expecting the Unexpected: Possible Adverse Effects for Lipid Modulating Agent Trials}

Based on the knowledge from RCTs in cardiovascular diseases, important adverse effects should be monitored when the results of these RCTs accrue. Myopathy is the most common adverse effect of statin use and is managed by conversion to other statin formulations. Severe muscle complications (i.e., rhabdomyolysis) are exceedingly rare (66). Rise in liver enzymes is another 
medRxiv preprint doi: https://doi.org/10.1101/2021.05.03.21256468; this version posted May 5, 2021. The copyright holder for this preprint (which was not certified by peer review) is the author/funder, who has granted medRxiv a license to display the preprint in perpetuity.

All rights reserved. No reuse allowed without permission.

potential but infrequent adverse effect. Fibrates may also increase the risk of myopathy and hepatocyte injury (67). Drug-drug interactions play an important role in this increased risk, and is considered in the ongoing COVID-19 RCTs (68). Other risks associated with statin use including hemorrhagic stroke in those with previous stroke are not of clinically important magnitude (6971). New-onset or worsening of atrial fibrillation is a concern with omega-3 fatty acids (72-74) and increased bleeding due to the effects on platelet aggregation should be monitored in the RCT results.

The adverse effects of niacin include flushing, pruritus, gastrointestinal disorder, thrombocytopenia, hyperuricemia, hyperglycemia, myopathy, and hepatotoxicity (75). Only the NIRVANA trial assesses thrombocytopenia as a safety outcome and excluded patients with liver disease.

These potential risks are limited by the short duration of treatment in most trials. Of note, the adverse events in massive event-driven cardiovascular trials result from multiple months to years of treatment, whereas the current COVID-19 trials generally have much shorter treatment duration. The possible adverse effects of lipid modulating agents are illustrated in Figure 2.

\section{CONCLUSIONS}

Lipid modulating agents may mitigate the multiorgan damage associated with COVID-19 through anti-inflammatory, anti-viral, and pleiotropic effects. Findings from ongoing rigorously conducted and adequately powered RCTs can assess the possible efficacy of lipid modulating agents in the prevention or treatment of various stages of COVID-19, and may open new horizons for research and clinical practice.

\section{DISCLOSURES}


medRxiv preprint doi: https://doi.org/10.1101/2021.05.03.21256468; this version posted May 5, 2021. The copyright holder for this preprint (which was not certified by peer review) is the author/funder, who has granted medRxiv a license to display the preprint in perpetuity.

Dr. Talasaz has no disclosures.

Dr. Sadeghipour has no disclosures.

Dr. Aghakouchakzadeh has no disclosures.

Dr. Dreyfus has no disclosures.

Dr. Kakavand has no disclosures.

Dr. Ariannejad has no disclosures.

Dr. Gupta received payment from the Arnold \& Porter Law Firm for work related to the Sanofi clopidogrel litigation and from the Ben C. Martin Law Firm for work related to an inferior vena cava filter litigation; received consulting fees from Edward Lifesciences; and holds equity in the healthcare telecardiology startup Heartbeat Health.

Dr. Madhavan was supported by a grant from the National Institutes of Health/National Heart, Lung, and Blood Institute to Columbia University Irving Medical Center (T32 HL007854).

Dr. Van Tassell has received research support from Novartis, Swed- ish Orphan Biovitrum, Olatec Therapeutics, and Serpin Pharma; and is a consultant of R-Pharm and Serpin Pharma.

Dr. Jimenez has served as an advisor or consultant for Bayer HealthCare Pharmaceuticals, Boehringer Ingelheim, Bristol Myers Squibb, Daiichi-Sankyo, Leo Pharma, Pfizer, ROVI, and Sanofi; has served as a speaker or a member of a speaker bureau for Bayer HealthCare Pharmaceuticals, Boehringer Ingelheim, Bristol Myers Squibb, Daiichi-Sankyo, Leo Pharma, ROVI, and Sanofi; and has received grants for clinical research from Daiichi-Sankyo, Sanofi, and ROVI.

Dr. Monreal has served as an advisor or consultant for Sanofi, Leo Pharma, and Daiichi-Sankyo; and has received a nonrestricted educational grant by Sanofi and Bayer to sponsor the Computerized Registry of Patients with Venous Thromboembolism. 
medRxiv preprint doi: https://doi.org/10.1101/2021.05.03.21256468; this version posted May 5, 2021. The copyright holder for this preprint (which was not certified by peer review) is the author/funder, who has granted medRxiv a license to display the preprint in perpetuity.

All rights reserved. No reuse allowed without permission.

Dr. Vaduganathan has received research grant support or served on advisory boards for American Regent, Amgen, AstraZeneca, Bayer AG, Baxter Healthcare, Boehringer Ingelheim, Cytokinetics, Lexicon Pharmaceuticals, and Relypsa, participates in speaker engagements with Novartis and Roche Diagnostics, and participates on clinical endpoint committees for studies sponsored by Galmed, Novartis, and the NIH.

Dr. Fanikos has served as a consultant for Portola, Inc. and Pfzer, Inc.

Dr. Dixon has no disclosures.

Dr. Piazza reports research grant support from BSC, Bayer, Bristol Myers Squibb/Pfizer Alliance, Portola, Amgen, and Janssen and consulting fees from Amgen, Pfizer, and BSC.

Dr. Parikh reports serving as a non-compensated advisor to Abbott Vascular, Boston Scientific, Cardiovascular Systems Inc, Cordis, Janssen, Medtronic, and Philips. He receives institutional research support from Abbott Vascular, Boston Scientific, Surmodics, TriReme, and Veryan Medical. He is a consultant to Abiomed, Inari Medical, Penumbra and Terumo.

Dr. Bhatt discloses the following relationships - Advisory Board: Cardax, CellProthera, Cereno Scientific, Elsevier Practice Update Cardiology, Janssen, Level Ex, Medscape Cardiology, MyoKardia, Novo Nordisk, PhaseBio, PLx Pharma, Regado Biosciences; Board of Directors: Boston VA Research Institute, Society of Cardiovascular Patient Care, TobeSoft; Chair: American Heart Association Quality Oversight Committee; Data Monitoring Committees: Baim Institute for Clinical Research (formerly Harvard Clinical Research Institute, for the PORTICO trial, funded by St. Jude Medical, now Abbott), Cleveland Clinic (including for the ExCEED trial, funded by Edwards), Contego Medical (Chair, PERFORMANCE 2), Duke Clinical Research Institute, Mayo Clinic, Mount Sinai School of Medicine (for the ENVISAGE trial, funded by Daiichi Sankyo), Population Health Research Institute; Honoraria: American College of Cardiology (Senior 
medRxiv preprint doi: https://doi.org/10.1101/2021.05.03.21256468; this version posted May 5, 2021. The copyright holder for this preprint (which was not certified by peer review) is the author/funder, who has granted medRxiv a license to display the preprint in perpetuity.

All rights reserved. No reuse allowed without permission.

Associate Editor, Clinical Trials and News, ACC.org; Vice-Chair, ACC Accreditation Committee), Baim Institute for Clinical Research (formerly Harvard Clinical Research Institute; RE-DUAL PCI clinical trial steering committee funded by Boehringer Ingelheim; AEGIS-II executive committee funded by CSL Behring), Belvoir Publications (Editor in Chief, Harvard Heart Letter), Canadian Medical and Surgical Knowledge Translation Research Group (clinical trial steering committees), Duke Clinical Research Institute (clinical trial steering committees, including for the PRONOUNCE trial, funded by Ferring Pharmaceuticals), HMP Global (Editor in Chief, Journal of Invasive Cardiology), Journal of the American College of Cardiology (Guest Editor; Associate Editor), K2P (Co-Chair, interdisciplinary curriculum), Level Ex, Medtelligence/ReachMD (CME steering committees), MJH Life Sciences, Population Health Research Institute (for the COMPASS operations committee, publications committee, steering committee, and USA national co-leader, funded by Bayer), Slack Publications (Chief Medical Editor, Cardiology Today's Intervention), Society of Cardiovascular Patient Care (Secretary/Treasurer), WebMD (CME steering committees); Other: Clinical Cardiology (Deputy Editor), NCDR-ACTION Registry Steering Committee (Chair), VA CART Research and Publications Committee (Chair); Research Funding: Abbott, Afimmune, Amarin, Amgen, AstraZeneca, Bayer, Boehringer Ingelheim, Bristol-Myers Squibb, Cardax, Chiesi, CSL Behring, Eisai, Ethicon, Ferring Pharmaceuticals, Forest Laboratories, Fractyl, HLS Therapeutics, Idorsia, Ironwood, Ischemix, Janssen, Lexicon, Lilly, Medtronic, MyoKardia, Novo Nordisk, Owkin, Pfizer, PhaseBio, PLx Pharma, Regeneron, Roche, Sanofi, Synaptic, The Medicines Company; Royalties: Elsevier (Editor, Cardiovascular Intervention: A Companion to Braunwald's Heart Disease); Site Co-Investigator: Abbott, Biotronik, Boston Scientific, CSI, St. Jude Medical (now 
medRxiv preprint doi: https://doi.org/10.1101/2021.05.03.21256468; this version posted May 5, 2021. The copyright holder for this preprint (which was not certified by peer review) is the author/funder, who has granted medRxiv a license to display the preprint in perpetuity.

All rights reserved. No reuse allowed without permission.

Abbott), Svelte; Trustee: American College of Cardiology; Unfunded Research: FlowCo, Merck, Takeda.

Dr Lip Consultant and speaker for BMS/Pfizer, Boehringer Ingelheim and Daiichi-Sankyo. No fees are received personally.

Dr. Stone has received speaker or other honoraria from Cook, Terumo, and Orchestra Biomed; has been a consultant to Valfix, TherOx, Vascular Dynamics, Robocath, HeartFlow, Gore, Ablative Solutions, Miracor, Neovasc, V-Wave, Abiomed, Ancora, MAIA Pharmaceuticals, Vectorious, Reva, Matrizyme, and CardioMech; and has equity/op- tions from Ancora, Cagent, Applied Therapeutics, Biostar family of funds, SpectraWave, Orchestra Biomed, Aria, Cardiac Success, Med- Focus family of funds, and Valfix.

Dr. Krumholz has received per- sonal fees from UnitedHealth, IBM Watson Health, Element Science, Aetna, Facebook, Siegfried \& Jensen Law Firm, Arnold \& Porter Law Firm, Ben C. Martin Law Firm, and the National Center for Cardio- vascular Diseases (Beijing, China); has ownership in Hugo Health and Refactor Health; and has contracts from the U.S. Centers for Medicare \& Medicaid Services; and has received grants from Med- tronic, the U.S. Food and Drug Administration, Johnson \& Johnson, and the Shenzhen Center for Health Information, outside the sub- mitted work.

Dr. Libby is an unpaid consultant to, or involved in clinical trials for Amgen, AstraZeneca, Beren, Esperion Therapeutics, Ionis Pharmaceuticals, Kowa Pharmaceuticals, Novartis, Pfizer, Sanofi-Regeneron, and XBiotech, Inc and is a member of scientific advisory board for Amgen, Corvidia Therapeutics, CSL Behring, DalCor Pharmaceuticals, Genentech, Kowa Pharmaceuticals, Olatec Therapeutics, PlaqueTec, Kancera, Medimmune, Novartis, Novo Nordisk, and XBiotech, Inc. Dr. Libby is on the Board of Directors of XBiotech, Inc. Dr. Libby 
medRxiv preprint doi: https://doi.org/10.1101/2021.05.03.21256468; this version posted May 5, 2021. The copyright holder for this preprint (which was not certified by peer review) is the author/funder, who has granted medRxiv a license to display the preprint in perpetuity.

All rights reserved. No reuse allowed without permission.

has a financial interest in Xbiotech, a company developing therapeutic human antibodies. Dr.

Libby's interests were reviewed and are managed by Brigham and Women's Hospital and

Partners HealthCare in accordance with their conflict of interest policies. Dr. Libby's laboratory

has received research funding in the last 2 years from Novartis.

Dr. Goldhaber has received research support from Bayer, Boehringer Ingelheim, Bristol Myers

Squibb, Boston Scientific, Daiichi-Sankyo, Janssen, the National Heart, Lung, and Blood Institute, and the Thrombosis Research Institute; and has received consulting fees from Bayer, Agile, Boston Scientific, and Boehringer Ingelheim.

Dr. Bikdeli reports that he is a consulting expert, on behalf of the plaintiff, for litigation related to two specific brand models of IVC filters.

ACKNOWLEDGEMENTS: The authors would like to express their sincere gratitude to Fatemeh Esmaeili, MS, for her kind assistance in the preparation of the Figures. 
medRxiv preprint doi: https://doi.org/10.1101/2021.05.03.21256468; this version posted May 5, 2021. The copyright holder for this preprint (which was not certified by peer review) is the author/funder, who has granted medRxiv a license to display the preprint in perpetuity.

\section{REFERENCES}

1. Guo H, Huang M, Yuan Q, et al. The important role of lipid raft-mediated attachment in the infection of cultured cells by coronavirus infectious bronchitis virus beaudette strain. PLoS One. 2017;12:e0170123.

2. Cao X. COVID-19: immunopathology and its implications for therapy. Nat Rev Immunol. 2020;20:269-70.

3. Bikdeli B, Madhavan MV, Jimenez D, et al. COVID-19 and thrombotic or thromboembolic disease: implications for prevention, antithrombotic therapy, and follow-up: JACC state-of-the-art review. J Am Coll Cardiol. 2020;75:2950-73.

4. Libby P, Lüscher T. COVID-19 is, in the end, an endothelial disease. Eur Heart J. 2020;41:3038-44.

5. Oesterle A, Laufs U, Liao JK. Pleiotropic effects of statins on the cardiovascular system. Circ Res. 2017;120:229-43.

6. Masana L, Correig E, Ibarretxe D, et al. Low HDL and high triglycerides predict COVID19 severity. Sci Rep. 2021;11:1-9.

7. Sviridov D, Miller YI, Ballout RA, Remaley AT, Bukrinsky M. Targeting Lipid Rafts—A Potential Therapy for COVID-19. Front Immunol. 2020;11.

8. Sheahan T, Morrison TE, Funkhouser W, et al. MyD88 is required for protection from lethal infection with a mouse-adapted SARS-CoV. PLoS pathog. 2008;4:e1000240.

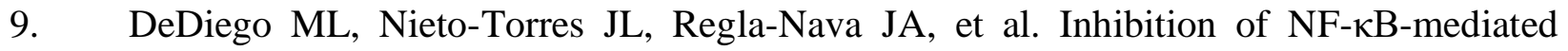
inflammation in severe acute respiratory syndrome coronavirus-infected mice increases survival. J Virol. 2014;88:913-24. 
medRxiv preprint doi: https://doi.org/10.1101/2021.05.03.21256468; this version posted May 5, 2021. The copyright holder for this preprint (which was not certified by peer review) is the author/funder, who has granted medRxiv a license to display the preprint in perpetuity.

All rights reserved. No reuse allowed without permission.

10. Hilgendorff A, Muth H, Parviz B, et al. Statins differ in their ability to block NF-kappaB activation in human blood monocytes. Int J Clin Pharmacol Ther. 2003;41:397-401.

11. Yuan S. Statins may decrease the fatality rate of Middle East respiratory syndrome infection. MBio. 2015;6.

12. Bikdeli B, Talasaz AH, Rashidi F, et al. Intermediate versus standard-dose prophylactic anticoagulation and statin therapy versus placebo in critically-ill patients with COVID-19: Rationale and design of the INSPIRATION/INSPIRATION-S studies. Thromb Res. 2020;196:382-94.

13. Ghati N, Roy A, Bhatnagar S, et al. Atorvastatin and Aspirin as Adjuvant Therapy in Patients with SARS-CoV-2 Infection: A structured summary of a study protocol for a randomised controlled trial. Trials. 2020;21:1-3.

14. Arnardottir H, Pawelzik S-C, Öhlund Wistbacka U, et al. Stimulating the Resolution of Inflammation Through Omega-3 Polyunsaturated Fatty Acids in COVID-19: Rationale for the COVID-Omega-F Trial. Front physiol. 2021;11:1748.

15. Ambrosy AP, Malik UI, Thomas RC, et al. Rationale and design of the pragmatic randomized trial of icosapent ethyl for high cardiovascular risk adults (MITIGATE). Am Heart J. 2021;235:54-64.

16. Lerner D, Garvey K, Arrighi-Allisan A, et al. Letter to the editor: Study SummaryRandomized Control Trial of Omega-3 Fatty Acid Supplementation for the Treatment of COVID19 Related Olfactory Dysfunction. Trials. 2020:942-.

17. REMAP-CAP: Randomized, Embedded, Multifactorial Adaptive Platform trial for Community-Acquired Pneumonia, Domain-Specific Appendix: Statin Therapy REMAP-CAP. REMAP-CAP. $\quad 2020 . \quad$ July Available at: 
medRxiv preprint doi: https://doi.org/10.1101/2021.05.03.21256468; this version posted May 5, 2021. The copyright holder for this preprint (which was not certified by peer review) is the author/funder, who has granted medRxiv a license to display the preprint in perpetuity.

All rights reserved. No reuse allowed without permission.

https://static1.squarespace.com/static/5cde3c7d9a69340001d79ffe/t/5f1bbb351849fd6f694bb8b5

/1595652928010/REMAP-CAP+Domain-Specific+Appendix+-+Simvastatin+Domain+V1.1+-

+23+July+2020 WM.pdf. Accessed July 23, 2020

18. kanagarantam P, Francis DP, Cole G, et al. Preventing Cardiac Complication of COVID-

19 Disease with Early Acute Coronary Syndrome Therapy: A Randomised Controlled Trial. Joint

Reseach Compliance Office. Joint Reseach Compliance Office. 2020. Available at: https://storage.googleapis.com/found-by-me/documents/trials/c-19-acs/Protocol\%20C-19-

ACS.pdf. Accessed October 12, 2020

19. Bhatt DL, Kumbhani DJ, Eagle KA. Effects of Icosapent Ethyl on Inflammatory Biomarkers in Individuals With COVID-19 - VASCEPA COVID-19 CardioLink-9. Paper presented at: National Lipid Association Virtual Scientific Sessions; December 12, 2020.

20. Cohen DE, Armstrong EJ. Pharmacology of cholesterol and lipoprotein metabolism2007.

21. Mehrbod P, Omar AR, Hair-Bejo M, Haghani A, Ideris A. Mechanisms of action and efficacy of statins against influenza. BioMed Res Int. 2014;2014.

22. SenBanerjee S, Lin Z, Atkins GB, et al. KLF2 Is a novel transcriptional regulator of endothelial proinflammatory activation. The Journal of experimental medicine. 2004;199:130515.

23. Merx MW, Weber C. Statins in the intensive care unit. Curr Opin Crit Care. 2006;12:30914.

24. Sun F, Duan W, Zhang Y, et al. Simvastatin alleviates cardiac fibrosis induced by infarction via up-regulation of TGF- $\beta$ receptor III expression. Br J Pharmacol. 2015;172:3779-92. 25. McAuley DF, Laffey JG, O'Kane CM, et al. Simvastatin in the acute respiratory distress syndrome. N Engl J Med. 2014;371:1695-703. 
medRxiv preprint doi: https://doi.org/10.1101/2021.05.03.21256468; this version posted May 5, 2021. The copyright holder for this preprint (which was not certified by peer review) is the author/funder, who has granted medRxiv a license to display the preprint in perpetuity.

All rights reserved. No reuse allowed without permission.

26. Truwit JD, Bernard GR, Matthay MA, et al. Rosuvastatin for sepsis-associated acute respiratory distress syndrome. N Engl J Med. 2014;370:2191-200.

27. Parihar SP, Guler R, Brombacher F. Statins: a viable candidate for host-directed therapy against infectious diseases. Nat Rev Immunol. 2019;19:104-17.

28. Calfee CS, Delucchi KL, Sinha P, et al. Acute respiratory distress syndrome subphenotypes and differential response to simvastatin: secondary analysis of a randomised controlled trial. Lancet Respir Med. 2018;6:691-8.

29. Feng Y. Efficacy of statin therapy in patients with acute respiratory distress syndrome/acute lung injury: a systematic review and meta-analysis. Eur Rev Med Pharmacol Sci. 2018;22:3190-8.

30. Gupta A, Madhavan MV, Poterucha TJ, et al. Association between antecedent statin use and decreased mortality in hospitalized patients with COVID-19. Nat Commun. 2021;12:1-9.

31. Pontes-Arruda A, DeMichele S, Seth A, Singer P. The use of an inflammation-modulating diet in patients with acute lung injury or acute respiratory distress syndrome: a meta-analysis of outcome data. J Parenter Enter Nutr. 2008;32:596-605.

32. Rogero MM, Leão MdC, Santana TM, et al. Potential benefits and risks of omega-3 fatty acids supplementation to patients with COVID-19. Free Radic Biol Med. 2020.

33. Davies SP, Mycroft-West CJ, Pagani I, et al. The hyperlipidaemic drug fenofibrate significantly reduces infection by SARS-CoV-2 in cell culture models. bioRxiv [Epub ahead of print]. 2021; https://doi.org/10.1101/2021.01.10.426114.

34. Mehmel M, Jovanović N, Spitz U. Nicotinamide riboside - the current State of research and therapeutic uses. Nutrients. 2020;12:1616. 
medRxiv preprint doi: https://doi.org/10.1101/2021.05.03.21256468; this version posted May 5, 2021. The copyright holder for this preprint (which was not certified by peer review) is the author/funder, who has granted medRxiv a license to display the preprint in perpetuity.

All rights reserved. No reuse allowed without permission.

35. Sorokin AV, Karathanasis SK, Yang ZH, et al. COVID-19-Associated dyslipidemia: Implications for mechanism of impaired resolution and novel therapeutic approaches. The FASEB Journal. 2020;34:9843-53.

36. Barter PJ, Caulfield M, Eriksson M, et al. Effects of Torcetrapib in Patients at High Risk for Coronary Events. N Engl J Med. 2007;357:2109-22.

37. Grundy SM, Stone NJ, Bailey AL, et al. 2018 AHA/ACC/AACVPR/AAPA/ABC/ACPM/ADA/AGS/APhA/ASPC/NLA/PCNA guideline on the management of blood cholesterol: a report of the American College of Cardiology/American Heart Association Task Force on Clinical Practice Guidelines. J Am Coll Cardiol. 2019;73:e285e350.

38. Mechanick JI, Rosenson RS, Pinney SP, et al. Coronavirus and Cardiometabolic Syndrome: JACC Focus Seminar. J Am Coll Cardiol. 2020;76:2024-35.

39. Sadeghipour P, Talasaz AH, Rashidi F, et al. Effect of Intermediate-Dose vs StandardDose Prophylactic Anticoagulation on Thrombotic Events, Extracorporeal Membrane Oxygenation Treatment, or Mortality Among Patients With COVID-19 Admitted to the Intensive Care Unit: The INSPIRATION Randomized Clinical Trial. JAMA. 2021.

40. Goligher EC, Bradbury CA, McVerry BJ, et al. Therapeutic Anticoagulation in Critically Ill Patients with Covid-19 - Preliminary Report. medRxiv [Epub ahead of print]. 2021;https://doi.org/10.1101/2021.03.10.21252749.

41. Talasaz AH, Sadeghipour P, Kakavand H, et al. Recent Randomized Trials of Antithrombotic Therapy for Patients With COVID-19: JACC State-of-the-Art Review. J Am Coll Cardiol. 2021. 
medRxiv preprint doi: https://doi.org/10.1101/2021.05.03.21256468; this version posted May 5, 2021. The copyright holder for this preprint (which was not certified by peer review) is the author/funder, who has granted medRxiv a license to display the preprint in perpetuity.

All rights reserved. No reuse allowed without permission.

42. Lee C, Choi WJ. Overview of COVID-19 inflammatory pathogenesis from the therapeutic perspective. Arch Pharm Res. 2021:1-18.

43. Wootton D. Dexamethasone in Hospitalized Patients with Covid-19. N Engl J Med. 2021;384:693-704.

44. Tomazini BM, Maia IS, Cavalcanti AB, et al. Effect of dexamethasone on days alive and ventilator-free in patients with moderate or severe acute respiratory distress syndrome and COVID-19: the CoDEX randomized clinical trial. JAMA. 2020;324:1307-16.

45. Dequin P-F, Heming N, Meziani F, et al. Effect of hydrocortisone on 21-day mortality or respiratory support among critically ill patients with COVID-19: a randomized clinical trial. JAMA. 2020;324:1298-306.

46. Sterne JA, Murthy S, Diaz JV, et al. Association between administration of systemic corticosteroids and mortality among critically ill patients with COVID-19: a meta-analysis. JAMA. 2020;324:1330-41.

47. Ramakrishnan S, Nicolau DV, Jr., Langford B, et al. Inhaled budesonide in the treatment of early COVID-19 (STOIC): a phase 2, open-label, randomised controlled trial. The Lancet Respiratory medicine. 2021.

48. López-Medina E, López P, Hurtado IC, et al. Effect of Ivermectin on Time to Resolution of Symptoms Among Adults With Mild COVID-19: A Randomized Clinical Trial. JAMA. 2021;325:1426-35.

49. Self WH, Semler MW, Leither LM, et al. Effect of Hydroxychloroquine on Clinical Status at 14 Days in Hospitalized Patients With COVID-19: A Randomized Clinical Trial. JAMA. 2020;324:2165-76. 
medRxiv preprint doi: https://doi.org/10.1101/2021.05.03.21256468; this version posted May 5, 2021. The copyright holder for this preprint (which was not certified by peer review) is the author/funder, who has granted medRxiv a license to display the preprint in perpetuity.

All rights reserved. No reuse allowed without permission.

50. Deftereos SG, Giannopoulos G, Vrachatis DA, et al. Effect of colchicine vs standard care on cardiac and inflammatory biomarkers and clinical outcomes in patients hospitalized with coronavirus disease 2019: the GRECCO-19 randomized clinical trial. JAMA network open. 2020;3:e2013136-e.

51. Lopes MI, Bonjorno LP, Giannini MC, et al. Beneficial effects of colchicine for moderate to severe COVID-19: a randomised, double-blinded, placebo-controlled clinical trial. RMD open. 2021;7:e001455.

52. Lan S-H, Lai C-C, Huang H-T, et al. Tocilizumab for severe COVID-19: a systematic review and meta-analysis. Int J Antimicrob Agents. 2020;56:106103.

53. Stone JH, Frigault MJ, Serling-Boyd NJ, et al. Efficacy of tocilizumab in patients hospitalized with Covid-19. N Engl J Med. 2020;383:2333-44.

54. Lee H-Y, Ahn J, Park J, et al. Beneficial Effect of Statins in COVID-19-Related Outcomes-Brief Report: A National Population-Based Cohort Study. Arterioscler Thromb Vasc Biol. 2021;41:e175-e82.

55. Duvall MG, Levy BD. DHA-and EPA-derived resolvins, protectins, and maresins in airway inflammation. Eur J Pharmacol. 2016;785:144-55.

56. Darwesh AM, Bassiouni W, Sosnowski DK, Seubert JM. Can N-3 polyunsaturated fatty acids be considered a potential adjuvant therapy for COVID-19-associated cardiovascular complications? Pharmacol Ther. 2020:107703.

57. Everhart A, Desai NR, Dowd B, et al. Physician variation in the de-adoption of ineffective statin and fibrate therapy. Health Serv Res. 2021.

58. Buschard K. Fenofibrate increases the amount of sulfatide which seems beneficial against Covid-19. Med Hypotheses. 2020;143:110127. 
medRxiv preprint doi: https://doi.org/10.1101/2021.05.03.21256468; this version posted May 5, 2021. The copyright holder for this preprint (which was not certified by peer review) is the author/funder, who has granted medRxiv a license to display the preprint in perpetuity.

All rights reserved. No reuse allowed without permission.

59. Nagai A, Matsumiya H, Hayashi M, et al. Effects of nicotinamide and niacin on bleomycininduced acute injury and subsequent fibrosis in hamster lungs. Experimental lung research. 1994;20:263-81.

60. Investigators* TA-H. Niacin in Patients with Low HDL Cholesterol Levels Receiving Intensive Statin Therapy. N Engl J Med. 2011;365:2255-67.

61. Group* TH-TC. Effects of Extended-Release Niacin with Laropiprant in High-Risk Patients. New England Journal of Medicine. 2014;371:203-12.

62. Schwartz GG, Olsson AG, Abt M, et al. Effects of dalcetrapib in patients with a recent acute coronary syndrome. N Engl J Med. 2012;367:2089-99.

63. Group* THTRC. Effects of Anacetrapib in Patients with Atherosclerotic Vascular Disease. N Engl J Med. 2017;377:1217-27.

64. Barter PJ, Caulfield M, Eriksson M, et al. Effects of torcetrapib in patients at high risk for coronary events. N Engl J Med. 2007;357:2109-22.

65. Bikdeli B, Barreto-Filho JA. Reducing the cardiovascular disease burden: justified means for getting to the end. Circ Cardiovasc Qual Outcomes. 2012;5:580-6.

66. Wood FA, Howard JP, Finegold JA, et al. N-of-1 Trial of a Statin, Placebo, or No Treatment to Assess Side Effects. N Engl J Med. 2020;383:2182-4.

67. Chen Y-Q, Zhao S-p, Ye H-J. Efficacy and safety of coenzyme A versus fenofibrate in patients with hyperlipidemia: a multicenter, double-blind, double-mimic, randomized clinical trial. Curr Med Res Opin. 2020;36:941-5.

68. Talasaz AH, Kakavand H, Van Tassell B, et al. Cardiovascular complications of COVID19: pharmacotherapy perspective. Cardiovasc Drugs Ther. 2020:1-11. 
medRxiv preprint doi: https://doi.org/10.1101/2021.05.03.21256468; this version posted May 5, 2021. The copyright holder for this preprint (which was not certified by peer review) is the author/funder, who has granted medRxiv a license to display the preprint in perpetuity.

All rights reserved. No reuse allowed without permission.

69. Adhyaru BB, Jacobson TA. Safety and efficacy of statin therapy. Nat Rev Cardiol. 2018;15:757-69.

70. Pandit A, Kumar P, Kumar A, et al. High-dose statin therapy and risk of intracerebral hemorrhage: a meta-analysis. Acta Neurol Scand. 2016;134:22-8.

71. Mach F, Ray KK, Wiklund O, et al. Adverse effects of statin therapy: perception vs. the evidence-focus on glucose homeostasis, cognitive, renal and hepatic function, haemorrhagic stroke and cataract. Eur Heart J. 2018;39:2526-39.

72. Bhatt DL, Steg PG, Miller M, et al. Cardiovascular risk reduction with icosapent ethyl for hypertriglyceridemia. N Engl J Med. 2019;380:11-22.

73. Kalstad AA, Myhre PL, Laake K, et al. Effects of n-3 fatty acid supplements in elderly patients after myocardial infarction: a randomized controlled trial. Circulation. 2020.

74. Lombardi M, Carbone S, Del Buono MG, et al. Omega-3 fatty acids supplementation and risk of atrial fibrillation: an updated meta-analysis of randomized controlled trials. Eur Heart $\mathbf{J}$ Cardiovasc Pharmacother. 2021.

75. Huber R, Wong A. Nicotinamide: An Update and Review of Safety \& Differences from Niacin. Skin Therapy Lett. 2020;25:7-11. 
medRxiv preprint doi: https://doi.org/10.1101/2021.05.03.21256468; this version posted May 5, 2021. The copyright holder for this preprint (which was not certified by peer review) is the author/funder, who has granted medRxiv a license to display the preprint in perpetuity.

All rights reserved. No reuse allowed without permission.

\section{HIGHLIGHTS}

- Lipid modulating agents have pleiotropic effects, including anti-viral, immunomodulatory, and antithrombotic properties that might help treat COVID-19.

- 36 RCTs are evaluating the impact of lipid modulating agents including statins, omega-3, fibrates, niacin, and CETP inhibitors for treatment of COVID-19.

- Omega-3 fatty acid preparations are being investigated for prevention of COVID-19 in 4 ongoing RCTs.

- Niacin is being assessed in 2 RCTs for post-acute-COVID-19. 
medRxiv preprint doi: https://doi.org/10.1101/2021.05.03.21256468; this version posted May 5, 2021. The copyright holder for this preprint (which was not certified by peer review) is the author/funder, who has granted medRxiv a license to display the preprint in perpetuity.

All rights reserved. No reuse allowed without permission.

\section{Figure legends}

Figure 1. PRISMA flow diagram. Caption: Key words used for search of clinicaltrials.gov. and WHO ICTRP included: COVID-19 or SARS-CoV-2 or Coronavirus disease 2019 with statin, atorvastatin, rosuvastatin, simvastatin, fluvastatin, lovastatin, pitavastatin, pravastatin, fibrate, fenofibrate, clofibrate, bezafibrate, gemfibrozil, pemafibrate, ezetimibe, bile acid sequestrant, colesevelam, cholestyramine, colestipol, omega, omega-3, icosapent ethyl, eicosapentaenoic acid, docosahexaenoic acid, PCSK9, PCSK9 inhibitors, Proprotein Convertase Subtilisin/Kexin type 9 alirocumab, evolocumab, inclisiran, niacin, nicotinic acid, nicotinamide, vitamin B3, evinacumab, bempedoic acid, mipomersen, lomitapide, cholesterol ester transfer protein inhibitors, CETP inhibitors, anacetrapib, dalcetrapib, evacetrapib, torcetrapib, and TA-8995. *: One trial identified by discussion with the principal investigator. COVID-19: Coronavirus Disease 2019, PCSK9: Proprotein Convertase Subtilisin/Kexin type 9, WHO ICTRP: World Health Organization International Clinical Trials Registry Platform.

Figure 2: Posited antiviral, immunomodulatory and antithrombotic mechanisms of lipid modulating agents in COVID-19 and their potential adverse effects.

Panel A: Within the alveoli, the initial binding of the SARS-CoV-2 to the pneumocytes results in innate immune cell (including macrophages and T-cells) infiltration and subsequent cytokine release. Statins, fibrates, omega-3, and niacin may exert immunomodulatory properties to reduce the severity of the inflammatory response. SARS-CoV-2 can downregulate ACE2 expression and reduce its protective effects in many tissues, but statins, fibrates, and omega-3 can maintain the alveoli's epithelial cell integrity by upregulating ACE2 and increasing the activity of endothelial 
medRxiv preprint doi: https://doi.org/10.1101/2021.05.03.21256468; this version posted May 5, 2021. The copyright holder for this preprint (which was not certified by peer review) is the author/funder, who has granted medRxiv a license to display the preprint in perpetuity.

All rights reserved. No reuse allowed without permission.

nitric oxide synthase. Statins may also alleviate collagen deposition and pulmonary fibrosis via upregulation of transforming growth factor beta receptor III.

Panel B: By destabilized the RBD of the viral spike protein and inhibiting RBD binding to ACE2, fibrates can inhibit viral entry. Statins and omega-3 fatty acids can also inhibit viral entry by disruption in cholesterol synthesis pathway and membranous lipid rafts. There is also some evidence showing the direct anti-viral effects of omega-3 fatty acids on enveloped viruses such as hepatitis C virus by causing leakage and disintegration of virus' envelope. Statins and niacin can also dampen viral replication via impacts on proteins of the replication pathway. Statin can reduce the prenylation of these proteins and niacin restores nicotinamide-adenine dinucleotide consuming enzyme with anti-viral functions, named as poly-ADP-ribose polymerases. Statin and niacin may have immunomodulatory effects via blocking of the reactive oxygen species.

Panel C: Within the vessel, lipid modulating agents can modulate the immune response and inhibit the cytokine storm. Omega-3 fatty acids can inhibit the antibody release from the B-cells and also prostaglandins. There is also some evidence showing that statins, fibrates, omega- 3 fatty acid, and dalcetrapib may have anti-platelet activities. Moreover, statins may have additional antithrombotic properties by inhibiting tissue factor, von Willebrand factor, factors V, XIII, and plasminogen activator inhibitor. Furthermore, high TG and non-HDL cholesterol is associated with worse outcomes; but it is still unclear that whether lowering triglyceride or non- high-density lipoprotein cholesterol can be used as a therapeutic intervention in COVID-19 or not.

Panel D: The possible adverse effects of lipid modulating agents are illustrated in Panel D.

ACE: Angiotensin Converting Enzyme; COVID-19: Coronavirus Disease 2019; HDL: highdensity lipoprotein, RBD: receptor binding domain; SARS-CoV-2: Severe Acute Respiratory Syndrome Coronavirus 2, TG: Triglyceride. 
medRxiv preprint doi: https://doi.org/10.1101/2021.05.03.21256468; this version posted May 5, 2021. The copyright holder for this preprint (which was not certified by peer review) is the author/funder, who has granted medRxiv a license to display the preprint in perpetuity.

Figure 3. Ongoing RCTs of statin therapy for Management of Patients with Diagnosed COVID-19. Caption: Statin therapy trials are evaluating patients in different settings including inpatients (ICU and non-ICU), and post-discharge settings. *: The full list of inclusion and exclusion criteria should be found in the original trial records; ${ }^{\dagger}$ : Patient enrollment setting includes hospitalized ICU or non-ICU patients and post-discharge settings. AEs: Adverse Events; Bpm: Beats per minute; COVID-19: Coronavirus Disease-2019; CK: Creatine Kinase; CrCl: Creatinine Clearance; CRP: C-Reactive Protein; CT: Computed Tomography; DC: Discharge; DDI: DrugDrug interaction; FRAIL: Fatigue Resistance, Ambulation, Illnesses, and Loss of weight questionnaire; GFR: Glomerular Filtration Rate; GI: Gastrointestinal; QTc: QT Corrected; HBV: Hepatitis B Virus; HCV: Hepatitis C Virus; ICU: Intensive Care Unit; LFT: Liver Function Tests; MI: Myocardial Ischemia; NP: Not Pointed; P/F ratio $(\mathrm{PaO} 2 / \mathrm{FiO} 2)$ ratio: The ratio of arterial oxygen partial pressure to fractional inspired oxygen; PCR: Polymerase Chain Reaction; PDE5: Phosphodiesterase type 5; RCT: Randomized Controlled Trial; SARS-CoV-2: Severe Acute Respiratory Syndrome-Coronavirus-2; SOC: Standard of Care; ULN: Upper Limit Normal; WHO: World Health Organization.

Figure 4. Ongoing RCTs of Omega-3 Fatty Acid Preparations for Management of Patients with Diagnosed COVID-19. Caption: Omega-3 fatty acid preparations are evaluating in different settings including inpatients non-ICU, and outpatient settings. *: The full list of inclusion and exclusion criteria should be found in the original trial records; ${ }^{\dagger}:$ Patient enrollment setting includes hospitalized non-ICU patients and outpatient settings. AIDS: Acquired Immunodeficiency Syndrome; BMI: Body Mass Index; CVD: Cardiovascular Disease; DHA: Docosahexaenoic Acid; 
medRxiv preprint doi: https://doi.org/10.1101/2021.05.03.21256468; this version posted May 5, 2021. The copyright holder for this preprint (which was not certified by peer review) is the author/funder, who has granted medRxiv a license to display the preprint in perpetuity.

All rights reserved. No reuse allowed without permission.

ESR: Erythrocyte Sedimentation Rate; EPA: Eicosapentaenoic Acid; FFA: Free Fatty Acid; HCQ: Hydroxychloroquine; hs-CRP: high-sensitivity C-Reactive Protein; IL-6: Interleukin-6; IV: Intravenous; LDH: Lactate Dehydrogenase; O2sat: Oxygen Saturation; qSOFA: quick Sequential Organ Failure Assessment; TNF- $\alpha$ : Tumor Necrosis Factor-alpha. Other abbreviations as in Figure 3.

Figure 5. Ongoing RCTs of fibrates therapy for Management of Patients with Diagnosed COVID-19. Caption: Fenofibrate is evaluating in different settings including inpatients non-ICU, and outpatient settings. *: The full list of inclusion and exclusion criteria should be found in the

original trial records; ${ }^{\dagger}:$ Patient enrollment setting includes hospitalized non-ICU patients and outpatient settings. MAP: Mean Arterial Pressure. Other abbreviations as in Figure 3 and Figure 4.

Figure 6. Ongoing RCTs of niacin therapy for Management of Patients with Diagnosed COVID-19. Caption: Niacin is evaluating in different settings including inpatients non-ICU, outpatient, and post-acute-COVID-19 settings. *: The full list of inclusion and exclusion criteria should be found in the original trial records; ${ }^{\dagger}$ : Patient enrollment setting includes hospitalized non-ICU patients, outpatient, and post-acute-COVID-19 settings. AKI: Acute Kidney Injury; CNS: Central Nervous System; eGFR: estimated Glomerular Filtration Rate; NAD: NicotinamideAdenine Dinucleotide; RRT: Renal Replacement Therapy. Other abbreviations as in Figure 3 and Figure 4 
medRxiv preprint doi: https://doi.org/10.1101/2021.05.03.21256468; this version posted May 5, 2021. The copyright holder for this preprint (which was not certified by peer review) is the author/funder, who has granted medRxiv a license to display the preprint in perpetuity.

Figure 7. Ongoing RCTs of Omega-3 Fatty Acid Preparations for Prevention of COVID-19.

Caption: Omega-3 fatty acid preparations are evaluating in moderate to high risk for COVID-19.

*: The full list of inclusion and exclusion criteria should be found in the original trial records. ACE:

Angiotensin Converting Enzyme; AF: Atrial Fibrillation; ASCVD: Atherosclerotic Cardiovascular

Disease; IL-1: Interleukin-1; IPE: Icosapent Ethyl; PCI: Percutaneous Coronary Intervention; RT-

PCR: Reverse Transcription Polymerase Chain Reaction; TNF- $\alpha$ : Tumor Necrosis Factor-alpha;

URI: Upper Respiratory Infection. Other abbreviations as in Figure 3 and Figure 4.

Central Illustration: Summary of ongoing lipid modulating agents' trials in COVID-19.

Caption: Statins are the most frequently studied lipid modulating agents in RCTs of patients with

COVID-19. Omega-3 fatty acid preparations are the only studied lipid modulating agents in prevention of COVID-19. Niacin is the only lipid modulating agent being studied for post-acute COVID-19. For more details please review Figure 3, 4 and 5. COVID-19: Coronavirus Disease 2019, FA: Fatty Acid, ICU: Intensive Care Unit, IPE: Icosapent ethyl, PCSK9: Proprotein Convertase Subtilisin/Kexin type 9. 


\begin{tabular}{|c|c|c|c|c|c|c|c|c|c|c|c|c|c|c|c|}
\hline \multirow[b]{3}{*}{ 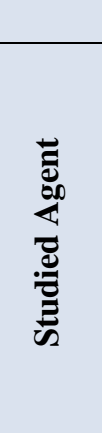 } & \multicolumn{15}{|c|}{ Table 1. Methodological Features of the Ongoing RCTs Categorized by the Drug Class } \\
\hline & $\stackrel{n}{\Xi}$ & $\stackrel{n}{=}$ & San & size & Enr & g Sites & & ator types & & ndin & & \multirow{2}{*}{ 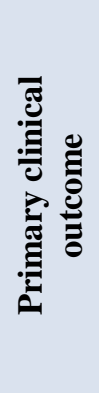 } & \multirow{2}{*}{ 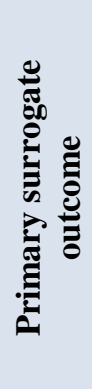 } & \multirow{2}{*}{ 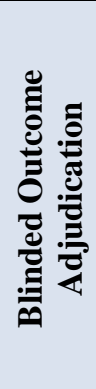 } & \multirow{2}{*}{ 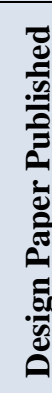 } \\
\hline & 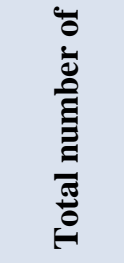 & 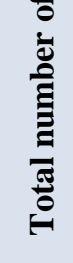 & 品 & 슷 & 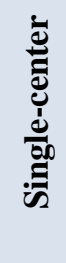 & & Placebo & $\begin{array}{c}\text { SOC/ No } \\
\text { intervention }\end{array}$ & 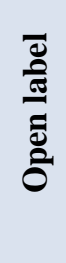 & $\begin{array}{l}\text { 茄 } \\
\text { 竞 }\end{array}$ & $\begin{array}{l}\frac{0}{0} \\
\bar{\Xi} \\
0\end{array}$ & & & & \\
\hline 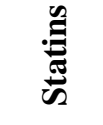 & 18,215 & 17 & 7 & 10 & 10 & 7 & 5 & 12 & 11 & 1 & 5 & 14 & 3 & 2 & 4 \\
\hline 窇 & 1,050 & 3 & 1 & 2 & 1 & 2 & 3 & - & - & - & 3 & 3 & 0 & 1 & - \\
\hline $\begin{array}{l}\text { 竎 } \\
\text { 离 }\end{array}$ & 1,200 & 5 & 4 & 1 & 4 & 1 & 5 & - & - & - & 5 & 4 & 1 & - & - \\
\hline 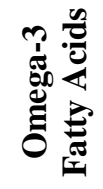 & 21,898 & 14 & 8 & 6 & 9 & 5 & 7 & 7 & 2 & 5 & 7 & 8 & 6 & - & 3 \\
\hline 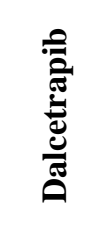 & 227 & 1 & - & 1 & - & 1 & 1 & - & - & - & 1 & 1 & - & - & - \\
\hline
\end{tabular}


medRxiv preprint doi: https://doi.org/10.1101/2021.05.03.21256468; this version posted May 5, 2021. The copyright holder for this preprint (which was not certified by peer review) is the author/funder, who has granted medRxiv a license to display the preprint in perpetuity.

All rights reserved. No reuse allowed without permission.

\section{Central Illustration. Summary of Ongoing Lipid Modulating Agents Trials in COVID-19}

\begin{tabular}{|c|c|c|c|c|c|c|}
\hline Lipid Lowering Agents Trials & \multicolumn{5}{|c|}{ Management of COVID-19 } & Prevention of COVID-19 \\
\hline & Outpatient & Floor & $\mathrm{ICU}$ & Post-discharge & Post-acute COVID-19 & \\
\hline Statin Trials & & $\underbrace{(v)}_{14 \text { trials }}$ & 4 trials & 1 trial & & \\
\hline Moderate Intensity Statin & - & 3 trials & 1 trial & 1 trial & - & - \\
\hline High Intensity Statin & $\cdot$ & 11 trials & 3 trials & - & $\cdot$ & $\cdot$ \\
\hline Omega3-FA preparations Trial & & & & & & \\
\hline Omega3-FA & $\begin{array}{l}4 \text { trials } \\
2 \text { trials }\end{array}$ & 6 trials & & & & 4 trials \\
\hline IPE & 2 trial & - & - & - & - & 2 trials \\
\hline Fibrates Trials & 2 trials & 3 trials & & & & \\
\hline Niacin Trials & 1 trial & 2 trials & & & 2 trials & \\
\hline Dalcetrapib Trials & $V_{1 \text { trial }}$ & & & & & \\
\hline 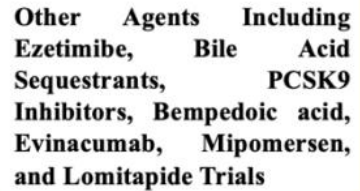 & & & & & 3 & \\
\hline
\end{tabular}


medRxiv preprint doi: https://doi.org/10.1101/2021.05.03.21256468; this version posted May 5, 2021. The copyright holder for this preprint (which was not certified by peer review) is the author/funder, who has granted medRxiv a license to display the preprint in perpetuity.

All rights reserved. No reuse allowed without permission.

Figure 1. PRISMA Flow Diagram

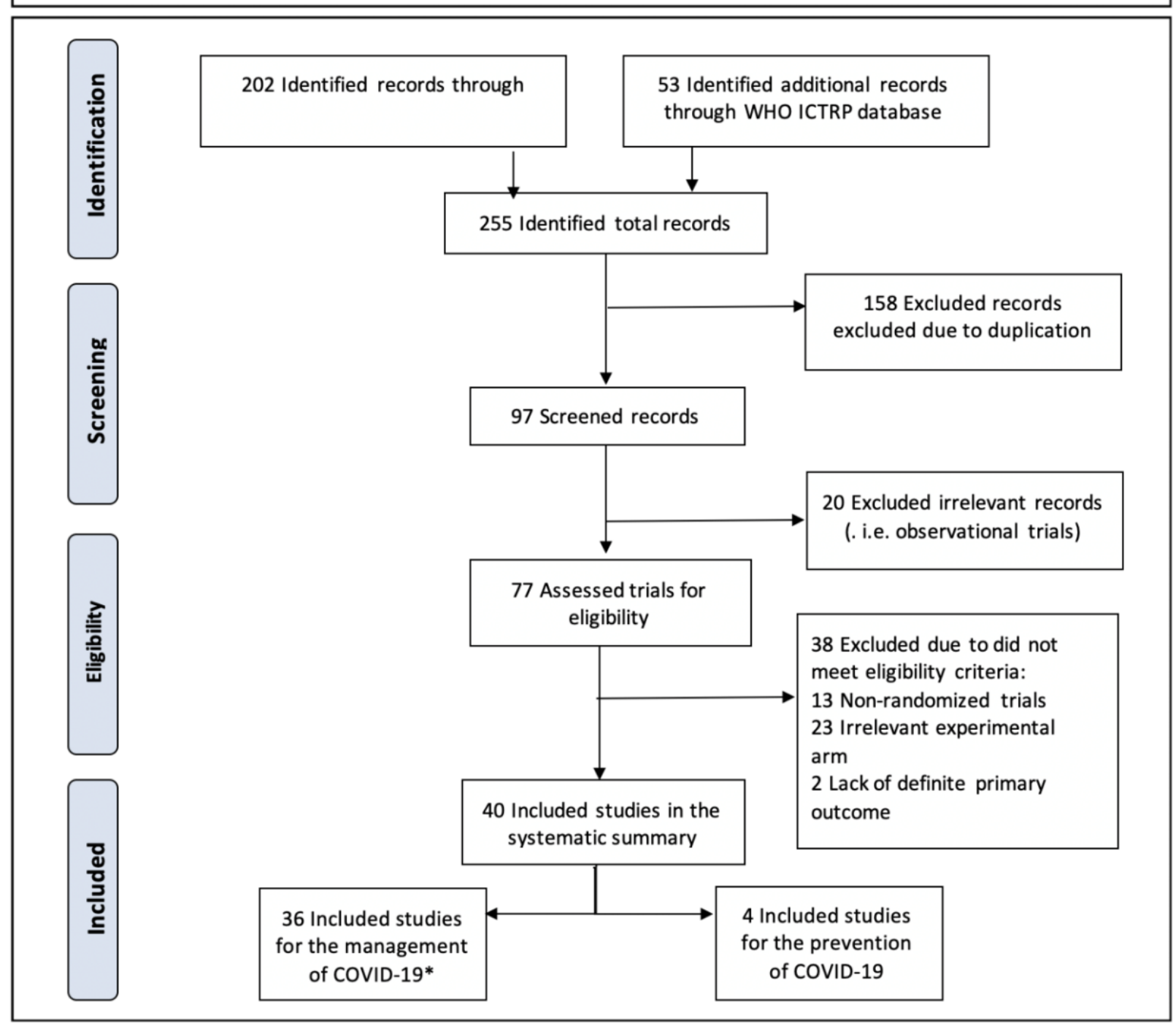


Figure 2: Potential benefits of lipid modulating agents in treating patients with COVID-19:

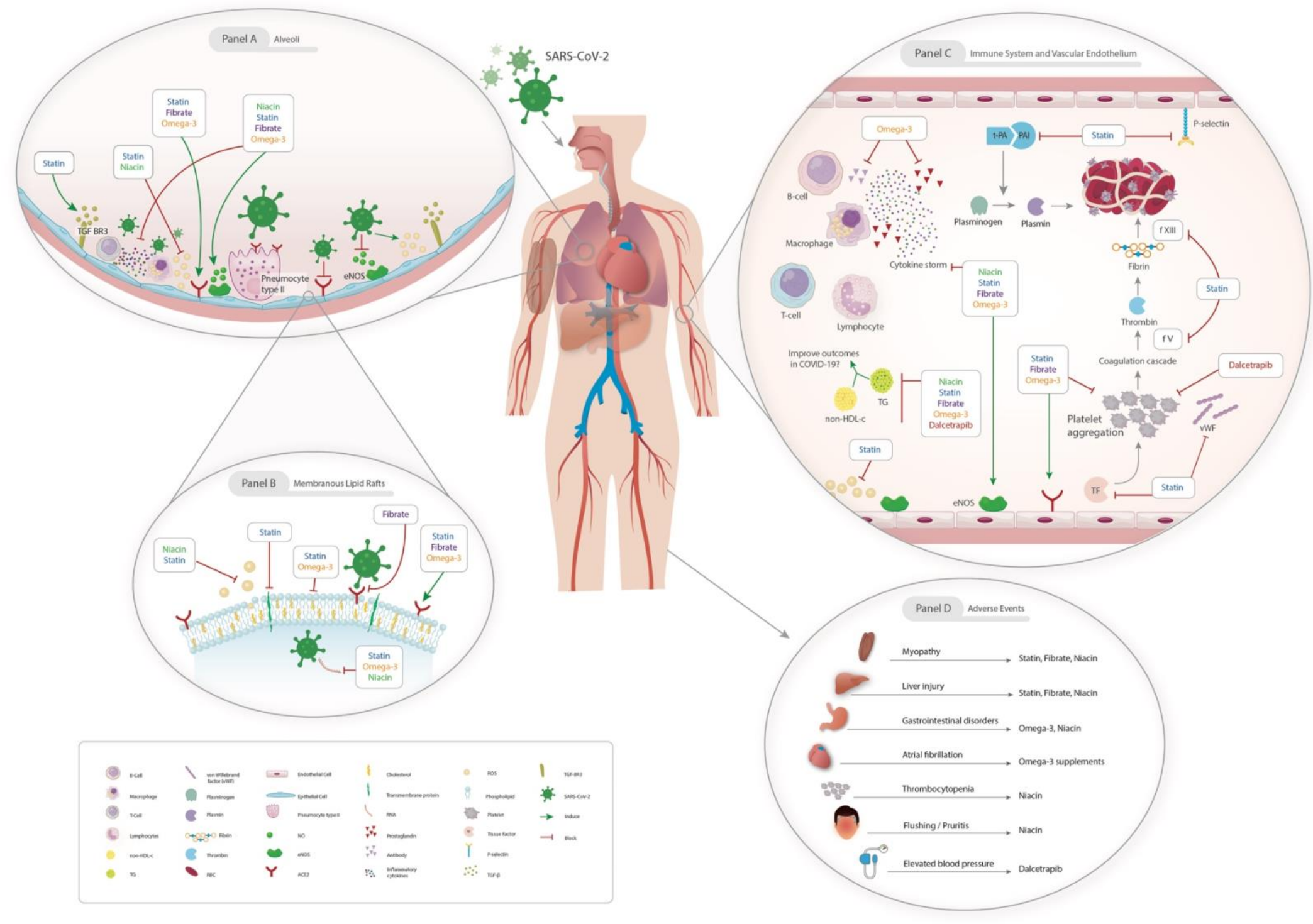


Figure 3. Ongoing RCTs of statin therapy for Management of Patients with Diagnosed COVID-19

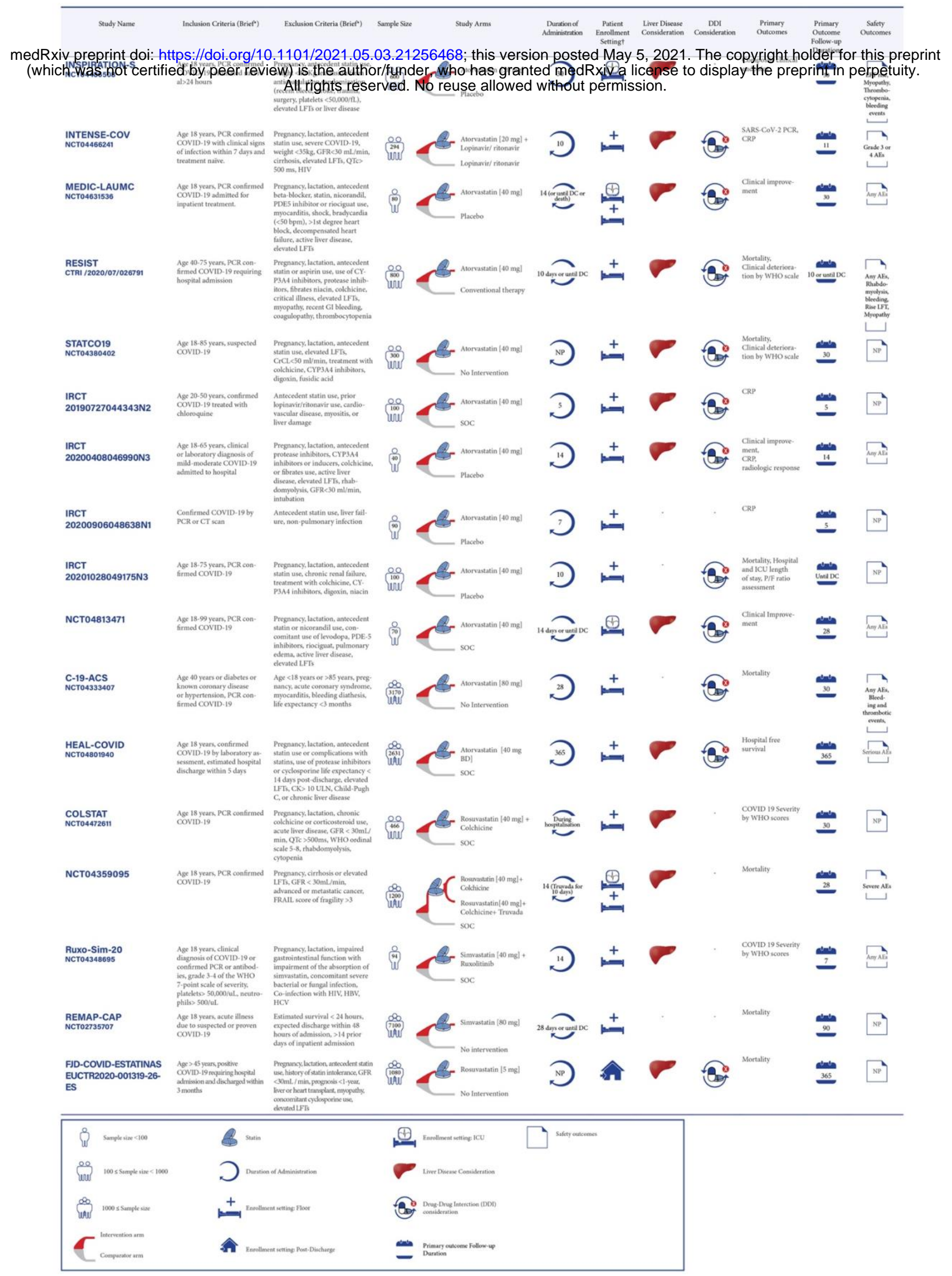


Figure 4. Ongoing RCTs of Omega-3 Fatty Acid Preparations for Management of Patients with Diagnosed COVID-19

medRxiv preprint doi: https://doi.org/10.1101/2021.05.03.21256468; this version posted May 5, 2021. The copyright holder for this preprint (which was not certified by peer review) is the author/funder, who has granted medRxiv a license to display the preprint in perpetuity.

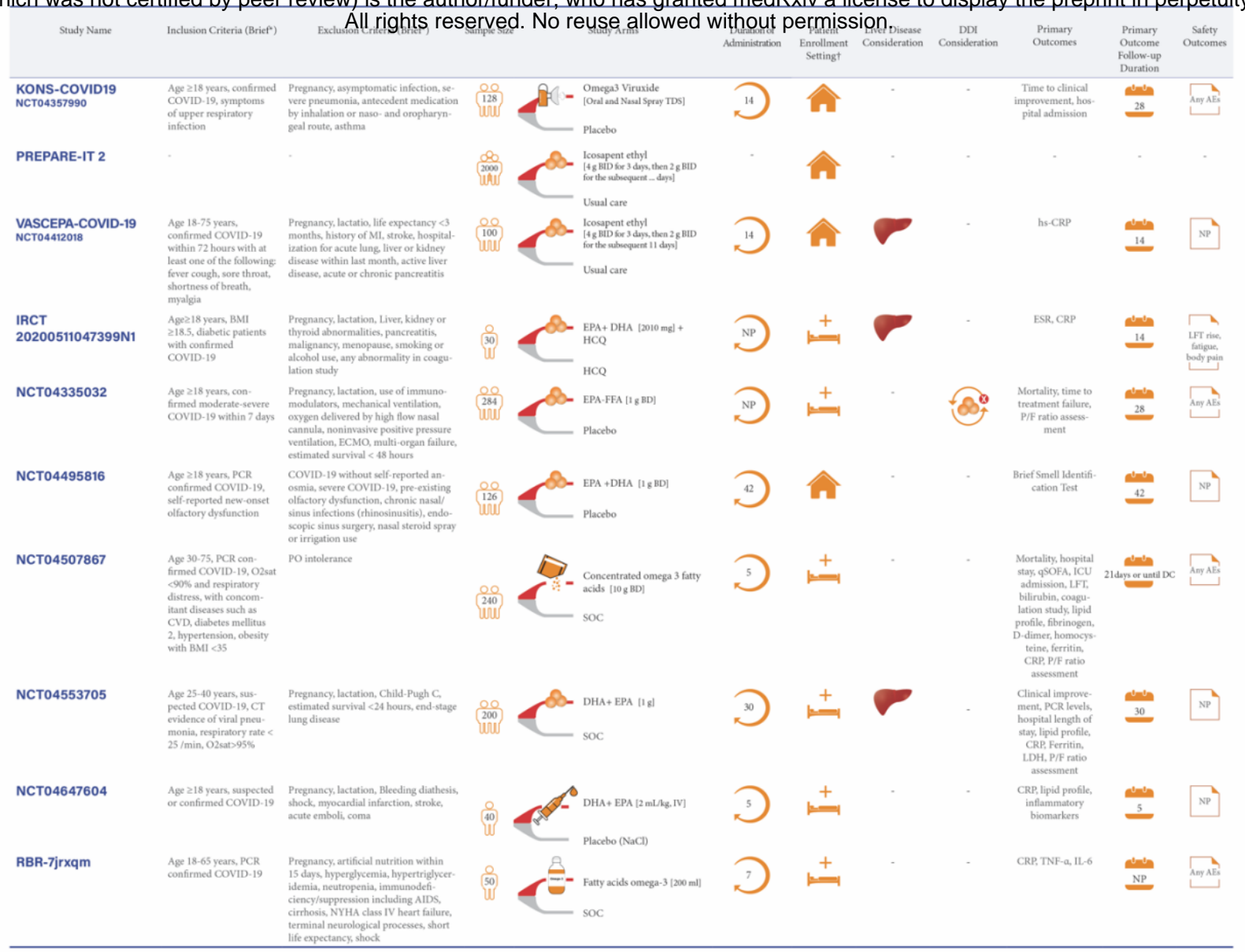

\begin{tabular}{|c|c|c|c|c|}
\hline \&it sumple ine $<100$ & D) Omeses pat & 令 & Omene-3linuid & $\boldsymbol{V}$ Liner Divemer Conideration \\
\hline Conet 100 s Somple tine $<1000$ & 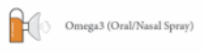 & $\supset$ & Duration of Adminitration & 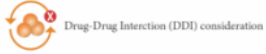 \\
\hline 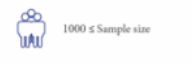 & 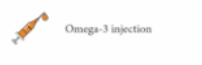 & $\hat{\mathrm{A}}$ & 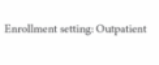 & 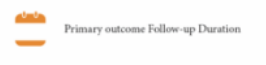 \\
\hline$C_{\text {Compratorermm }}^{\text {Internetion arm }}$ & 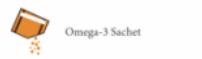 & \pm & Enrollment stiting floor & D sulky outcomes \\
\hline
\end{tabular}


Figure 5. Ongoing RCTs of Fibrates Therapy for Management of Patients with Diagnosed COVID-19

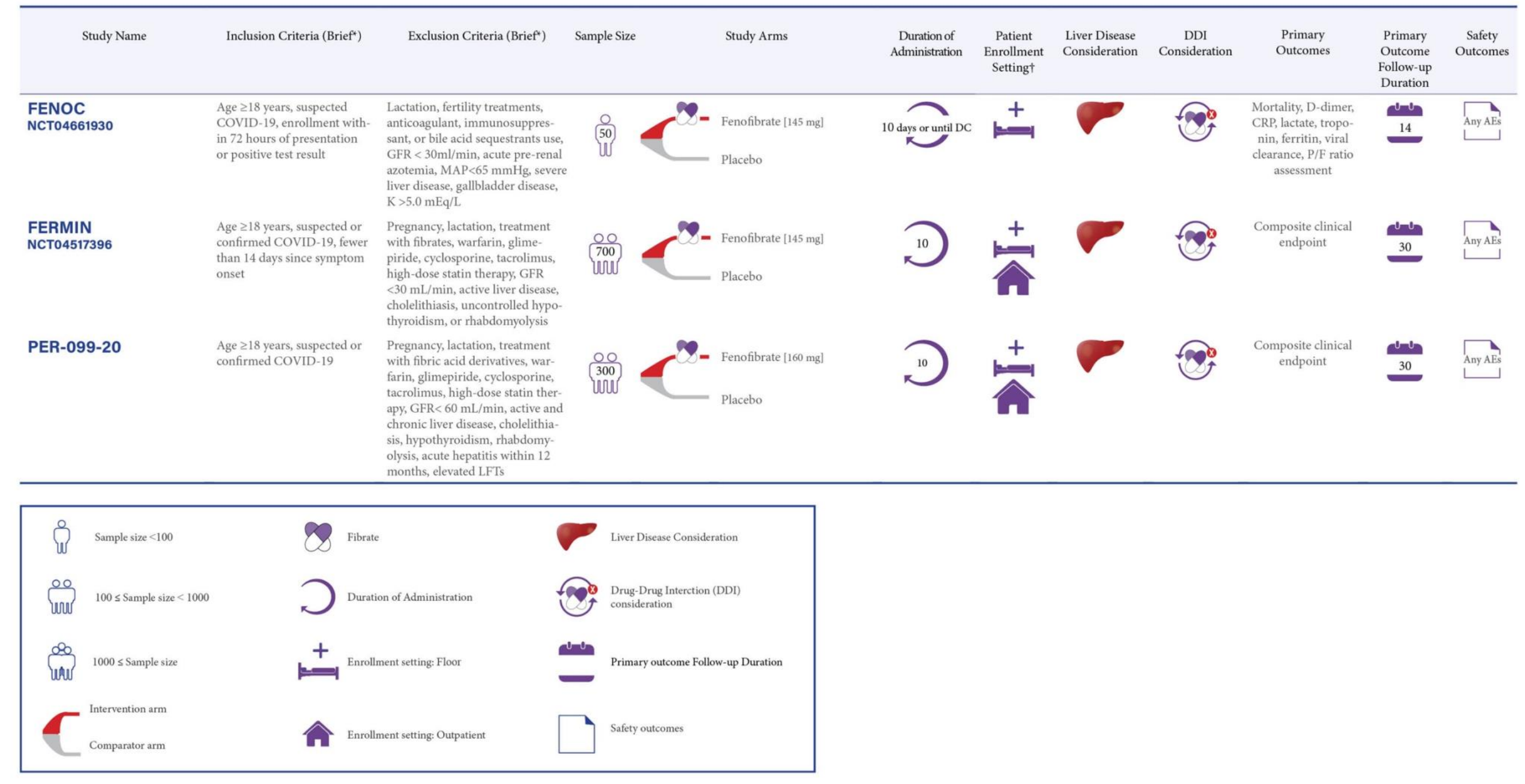


Figure 6. Ongoing RCTs of Niacin Therapy for Management of Patients with Diagnosed COVID-19

\begin{tabular}{|c|c|c|c|c|c|c|c|c|c|c|c|}
\hline Study Name & Inclusion Criteria (Brief') & Exclusion Criteria (Brief") & Sample Size & Study Arms & $\begin{array}{c}\text { Durntion of } \\
\text { Administration }\end{array}$ & $\begin{array}{l}\text { Patient } \\
\text { Enrolment } \\
\text { Settingt }\end{array}$ & $\begin{array}{l}\text { Liver Disease } \\
\text { Consideration }\end{array}$ & $\begin{array}{c}\text { DDI } \\
\text { Consideration }\end{array}$ & $\begin{array}{l}\text { Primary } \\
\text { Outcomes }\end{array}$ & $\begin{array}{l}\text { Primary } \\
\text { Outcome } \\
\text { Follow-up } \\
\text { Duration }\end{array}$ & $\begin{array}{l}\text { Safety } \\
\text { Outcomes }\end{array}$ \\
\hline $\begin{array}{l}\text { COVit-2 } \\
\text { NCT04751604 }\end{array}$ & $\begin{array}{l}\text { Age } \geq 18 \text { years, confirmed } \\
\text { COVID }-19 \text { within } 7 \text { days }\end{array}$ & None mentioned & $\begin{array}{l}80 \\
8000 \\
\text { uoul }\end{array}$ & $\begin{array}{l}\text { Nicotinamide [1 g] } \\
\text { Placebo }\end{array}$ & & & - & - & $\begin{array}{l}\text { Frequency of complete } \\
\text { symplom resolution }\end{array}$ & هلm & $\mathrm{NP}$ \\
\hline $\begin{array}{l}\text { Long-COVID } \\
\text { NCT04809974 }\end{array}$ & 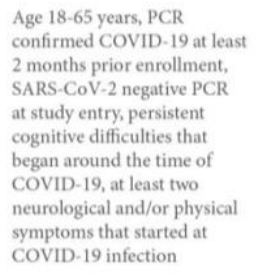 & $\begin{array}{l}\text { Pregnancy, lactation, any specific } \\
\text { CNS disease history, unstable } \\
\text { medical condition, history of } \\
\text { intubation due to COVID-19, } \\
\text { major active or chronic unstable } \\
\text { psychiatric illness within the } \\
\text { previous year, history of alcohol } \\
\text { or other substance abuse }\end{array}$ & $\begin{array}{l}00 \\
100 \\
\text { uoul }\end{array}$ & $\begin{array}{l}\text { Nicotinamide riboside } \\
{\left[\begin{array}{l}\text { 2g dalily }] \\
\text { Placebo }\end{array}\right.}\end{array}$ & & & & & $\begin{array}{l}\text { Assessment of cognitive } \\
\text { functioning }\end{array}$ & 154 & $\mathrm{NP}$ \\
\hline $\begin{array}{l}\text { NIRVANA } \\
\text { NCT04818216 }\end{array}$ & $\begin{array}{l}\text { Age } 218 \text { years, confirmed } \\
\text { COVID-19 } \\
\text { and evidence of persistent } \\
\text { AKI }\end{array}$ & 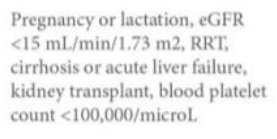 & $\begin{array}{l}100 \\
1000\end{array}$ & $\begin{array}{l}\text { Nicotinamide ribside } \\
\text { |c cap n } 50 \mathrm{Omg} \text { BDI } \\
\text { Placebo }\end{array}$ & & + & 2 & & Blood NAD + level & هـe & $\underset{\substack{\text { Severe cEs, } \\
\text { rombocytopen }}}{\square}$ \\
\hline $\begin{array}{l}\text { NR-COVID19 } \\
\text { NCT04407390 }\end{array}$ & $\begin{array}{l}\text { Age } 270 \text { years, confirmed } \\
\text { CovvD-19, BMM } 18-40 \mathrm{~kg} / \\
\mathrm{m} 2 \text { and weight } 240 \mathrm{~kg}\end{array}$ & $\begin{array}{l}\text { Need for oxygen therapy, } \\
\text { ongoing severe acute respiratory } \\
\text { syndrome, cancer diagnosis } \\
\text { within last } 5 \text { years }\end{array}$ & $\begin{array}{l}000 \\
1000 \\
1000\end{array}$ & $\begin{array}{l}\text { Nicotinami } \\
\text { Placebo }\end{array}$ & & + & - & - & Need for oxygen therapy & هond & ${ }_{\mathrm{NP}}$ \\
\hline NCT04604704 & $\begin{array}{l}\text { Age 18- } 65 \text { years, PCR } \\
\text { confirmed COVII-19, 1-4 } \\
\text { months prior enrollment, a } \\
\text { fatigue score above } 9 \text { in the } \\
\text { Chalder Fatigue scale upon } \\
\text { enrollment }\end{array}$ & 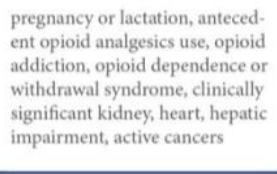 & $i_{60}^{\infty}$ & $\begin{array}{l}\text { Nicotinamide } \\
{[400 \mathrm{mg} \mid+ \text { Naltrexone }} \\
\text { Placebo }\end{array}$ & & & - & - & $\begin{array}{l}\text { Reduction of f fitigue } \\
\text { in post-C.CVID-19 } \\
\text { syndrome }\end{array}$ & هems & $\mathrm{NP}$ \\
\hline
\end{tabular}

Nif Sample size 1000


Figure 7. Ongoing RCTs of Omega-3 Fatty Acid Preparations for Prevention of COVID-19

\begin{tabular}{|c|c|c|c|c|c|c|c|c|c|c|}
\hline Study Name & Inclusion Criteria (Brief") & Exclusion Criteria (Brief') & Sample Size & Study Arms & $\begin{array}{c}\text { Duration of } \\
\text { Administration }\end{array}$ & $\begin{array}{l}\text { Liver Disease } \\
\text { Consideration }\end{array}$ & $\begin{array}{c}\text { DDI } \\
\text { Consideration }\end{array}$ & $\begin{array}{l}\text { Primary } \\
\text { Outcomes }\end{array}$ & $\begin{array}{l}\text { Primary } \\
\text { Outcome } \\
\text { Follow-up } \\
\text { Duration }\end{array}$ & $\begin{array}{l}\text { Safety } \\
\text { Outcomes }\end{array}$ \\
\hline $\begin{array}{l}\text { MITIGATE } \\
\text { NCT04505098 }\end{array}$ & $\begin{array}{l}\text { Age } 250 \text { years, no prior history } \\
\text { of confirmed COVID-19, estab- } \\
\text { lished ASCVD }\end{array}$ & $\begin{array}{l}\text { Pregnancy, antecedent IPE or ome- } \\
\text { ga-3 fatty acid use, hospitalization } \\
\text { for myocardial infarction or PCI } \\
\text { within Imonth, triple antithrom- } \\
\text { botic therapy, stage D heart failure, } \\
\text { severe liver idsease, GRR< } 15 \mathrm{~mL} / \\
\text { min, metastatic cancer, systemic } \\
\text { chemotherapy }\end{array}$ & $\frac{\infty}{16500}$ & $\begin{array}{l}\text { Icosapent ethyl }[2 \mathrm{~g} \mathrm{BD}] \\
\text { Placebo }\end{array}$ & At least & & 80 & $\begin{array}{c}\text { Percentage of patients } \\
\text { with moderate or } \\
\text { severe confirmed viral } \\
\text { URIs, wort clinical sta- } \\
\text { tus due to a confirmed } \\
\text { viral URI }\end{array}$ & 365 & $\stackrel{\text { Any AEs }}{\longrightarrow}$ \\
\hline $\begin{array}{l}\text { PREPARE-IT } 1 \\
\text { NCT04460651 }\end{array}$ & $\begin{array}{l}\text { Age } \geq 18 \text { years, hospital staff } \\
\text { working in ICU or emergen- } \\
\text { cy departments that care for } \\
\text { COVID-19 patients, people } \\
\text { performing aerosol-generating } \\
\text { procedures on COVID-19 } \\
\text { patients, relatives of COVID-19 } \\
\text { index cases with contact, labo- } \\
\text { ratory staff running COVID-19 } \\
\text { tests }\end{array}$ & $\begin{array}{l}\text { Pregnancy, lactation, anticoagulant } \\
\text { use, bleding diathesiss paroxys- } \\
\text { mal or persistent AF, Symptoms } \\
\text { consistent with COVDD-19 or } \\
\text { influenza- -like symptoms, previous } \\
\text { confirmed COVID-19 }\end{array}$ & $\begin{array}{l}000 \\
2000 \\
\text { unu }\end{array}$ & $\begin{array}{l}\text { Icosapent ethyl } \\
{[4 \mathrm{~g} \text { BID for } 3 \text { days, then } 2 \mathrm{~g} \text { BID }} \\
\text { for days } 4-60] \\
\text { Placebo }\end{array}$ & & & & $\begin{array}{l}\text { Percentage of SARS- } \\
\text { CoV-2 positive subjects } \\
\text { by RT-PCR or lgG anti- } \\
\text { bodies, severity disease } \\
\text { by WHO scale }\end{array}$ & 60 & $\stackrel{\mathrm{Any}_{\mathrm{AEs}}}{\longrightarrow}$ \\
\hline NCT04483271 & $\begin{array}{l}\text { Age } 30-66 \text { years without con- } \\
\text { firmed COVID-19 }\end{array}$ & $\begin{array}{l}\text { Pregnancy, lactation, hormonal } \\
\text { contraceptive use, autoimmune } \\
\text { disease, chronic or severe infections }\end{array}$ & $\begin{array}{l}00 \\
100 \\
\text { uou }\end{array}$ & $\begin{array}{l}\text { Omega3-FA [300 mg] } \\
\text { No intervention }\end{array}$ & & & & IL-1beta, IL-6, TNF- $a$ & $\frac{0.1}{60}$ & $\mathrm{NP}^{2}$ \\
\hline NCT04658433 & $\begin{array}{l}\text { Age } 35-65 \text { years, without con- } \\
\text { firmed COVID-19 }\end{array}$ & $\begin{array}{l}\text { Pregnancy, lactation, hormonal } \\
\text { contraceptives use, CVD, diabetes, } \\
\text { autoimmune diseases, chronic or } \\
\text { severe infections }\end{array}$ & $\begin{array}{l}00 \\
100 \\
\text { uou }\end{array}$ & $\begin{array}{l}\text { Omega3-FA [300 mg] } \\
\text { No intervention }\end{array}$ & & & & $\begin{array}{l}\text { Serum ACE and ACE2 } \\
\text { levels }\end{array}$ & דata & ${ }_{\mathrm{NP}}$ \\
\hline
\end{tabular}

$100 \leq$ Sample size $<1000$

